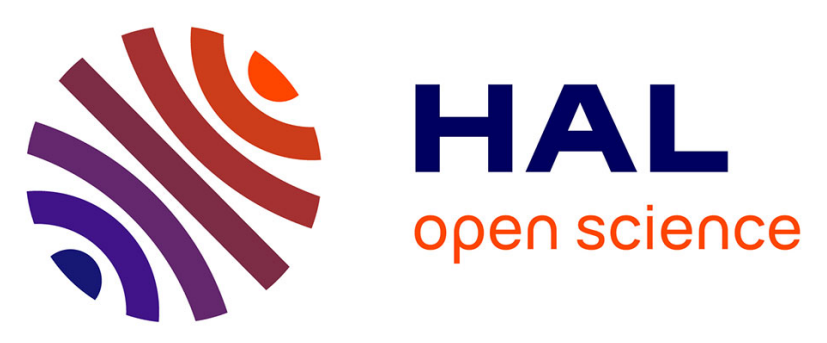

\title{
Biodegradation of Emiliania huxleyi aggregates by a natural Mediterranean prokaryotic community under increasing hydrostatic pressure
}

Virginie Riou, Julien Para, Marc Garel, Catherine Guigue, Badr Al Ali, Chiara Santinelli, Dominique Lefèvre, Jean-Pierre Gattuso, Madeleine Goutx, Stephanie Jacquet, et al.

\section{To cite this version:}

Virginie Riou, Julien Para, Marc Garel, Catherine Guigue, Badr Al Ali, et al.. Biodegradation of Emiliania huxleyi aggregates by a natural Mediterranean prokaryotic community under increasing hydrostatic pressure. Progress in Oceanography, 2018, 163, pp.271-281. 10.1016/j.pocean.2017.01.005 . hal-01975994

\author{
HAL Id: hal-01975994 \\ https://hal.science/hal-01975994
}

Submitted on 9 Jan 2019

HAL is a multi-disciplinary open access archive for the deposit and dissemination of scientific research documents, whether they are published or not. The documents may come from teaching and research institutions in France or abroad, or from public or private research centers.
L'archive ouverte pluridisciplinaire HAL, est destinée au dépôt et à la diffusion de documents scientifiques de niveau recherche, publiés ou non, émanant des établissements d'enseignement et de recherche français ou étrangers, des laboratoires publics ou privés. 


\section{Biodegradation of Emiliania huxleyi Aggregates by a Natural}

\section{Mediterranean Prokaryotic Community under Increasing}

\section{Hydrostatic Pressure}

4Virginie Riou ${ }^{1,2}$, Julien Para ${ }^{1}$, Marc Garel ${ }^{1}$, Catherine Guigue ${ }^{1}$, Badr Al Ali $^{1,3}$, Chiara Santinelli ${ }^{4}$, 5Dominique Lefèvre ${ }^{1}$, Jean-Pierre Gattuso ${ }^{5,6}$, Madeleine Gout ${ }^{1}$, Stephanie Jacquet ${ }^{1}$, Frédéric A.C. Le 6Moigne ${ }^{7}$, Kazuyo Tachikawa ${ }^{2}$ and Christian Tamburini ${ }^{1, *}$

7(1) Aix Marseille Université, Université Toulon, CNRS, IRD, MIO UM 110, Mediterranean Institute of 80ceanography, Marseille, France

9(2) CEREGE, UM34, Aix Marseille Université, CNRS, IRD, Aix-en-Provence Cedex, France

10(3) Ministry of Higher Education, Tishreen University, High Institute of Marine Research, LATTAKIA, Syria

11(4) C.N.R., Istituto di Biofisica, Pisa, Italy

12 (5) Sorbonne Universités, UPMC Univ Paris 06, CNRS-INSU, Laboratoire d'Océanographie de Villefranche, 181 13chemin du Lazaret, F-06230 Villefranche-sur-mer, France

14(6) Institute for Sustainable Development and International Relations, Sciences Po, 27 rue Saint Guillaume, F1575007 Paris, France

16(7) GEOMAR Helmholtz Centre for Ocean Research Kiel, Kiel, Germany

17* Corresponding author: christian.tamburini@mio.osupytheas.fr 


\section{Abstract}

19In the deep ocean, fluxes of particulate organic carbon (POC) and calcium carbonate are positively 20correlated, suggesting that $\mathrm{CaCO}_{3}$ could increase sinking particle densities and/or protect the organic 21matter from degradation by prokaryotes, the so called "ballast effect". Here, we used the PArticle 22Sinking Simulator system to investigate the effect of increasing pressure on the biodegradation of 23calcifying Emiliania huxleyi aggregates. A ten days incubation was performed, simulating the changes 24in temperature and pressure experienced in situ in the NW Mediterranean Sea. Aggregates sinking 25 from $200 \mathrm{~m}$ to $1700 \mathrm{~m}$ depth (assuming an average sinking velocity of $150 \mathrm{~m} \mathrm{~d}^{-1}$ ) were exposed to a 26fresh natural mesopelagic prokaryotic community, with limited influence of culture-associated 27prokaryotes. E. huxleyi aggregates lipid composition revealed more degradation under increasing 28hydrostatic pressure (relative to constant atmospheric pressure), suggesting increased cell lysis. In 29parallel, changes in particulate inorganic carbon and total alkalinity indicated $\mathrm{CaCO}_{3}$ dissolution, 30potentially accelerated under pressure. However, increased hydrostatic pressure also had a positive 31 effect on particle aggregation, which may compensate the effect of increased cell lysis. Our results 32imply that in coccolithophorid-dominated sinking aggregates, the ballasting and protection effects of 33 coccoliths may collapse throughout the water column. The increase in aggregation potential with 34pressure observed in controlled conditions might balance the loss of mineral ballast to a certain 35extent, although this needs to be confirmed in situ.

36Keyword: biological carbon pump; mesopelagic; mineral ballast; coccolithophorid; prokaryotes; 37biodegradation; hydrostatic pressure 


\section{Introduction}

39The ocean's biological carbon pump transports carbon into the deep ocean in the form of organic 40matter (Eppley and Peterson, 1979). Between 1-40\% of the organic carbon newly formed from $\mathrm{CO}_{2}$ 41fixation at the sea surface is transported to the deep sea (Ducklow et al., 2001), away from direct 42contact with the atmosphere. This process absorbs a large portion of the anthropogenic $\mathrm{CO}_{2}$ 43emissions in the atmosphere, limiting greenhouse $\mathrm{CO}_{2}$ gas build-up (Le Quéré et al., 2010). However, 44many climate-sensitive factors can influence organic carbon export and remineralization by 45mesopelagic heterotrophs, such as the mineral content of sinking particles (Armstrong et al., 2001; 46Kwon et al., 2009).

47Globally, approximately 5-20 Pg C yr ${ }^{-1}$ leaves the euphotic zone (20-120m depth) in the form of 48sinking particulate organic carbon (POC) (Henson et al., 2011; Siegel et al., 2014). However, most of 49this POC is potentially remineralized to $\mathrm{CO}_{2}$ in the upper mesopelagic zone (Buesseler and Boyd, 502009; Giering et al., 2014), where the activity of particle-attached prokaryotes and zooplankton play 51an important role in POC attenuation (Cho and Azam, 1988; Giering et al., 2014; Turley and Mackie, 521994, 1995). On one hand, sinking POC collected in situ can be rapidly remineralized by attached 53prokaryotes, as demonstrated by incubations done at atmospheric pressure (Goutx et al., 2007; 54Panagiotopoulos et al., 2002; Sempéré et al., 2000). On the other hand, the remineralisation of 55sinking particles (diatom aggregates or faecal pellets) and dissolution of biogenic minerals (opal) by 56 fresh natural surface prokaryotic assemblages were observed to slow down under increasing pressure 57(Tamburini et al., 2006, 2009). Correlation between POC and mineral fluxes (calcium carbonate, opal, 58clays) in the deep ocean has lead to the interpretation that "ballast" minerals exert an important 59control over POC export (Armstrong et al., 2001; Francois et al., 2002; Klaas and Archer, 2002).

600ceanic provinces in which calcifying plankton dominates display lower mesopelagic remineralisation 61fluxes than systems dominated by opal-producing diatoms (Cardinal et al., 2001, 2005; Jacquet et al., 622005). In sinking particles collected in situ, the presence of minerals has been suggested to preserve 
63organic matter from degradation (Hedges et al., 2001; Ingalls et al., 2003). These observations suggest 64that mineral and POC dissolutions in the water column may be inter-related. To understand these 65interactions, a few biodegradation studies have been conducted using aggregates obtained from 66cultures of opal-protected diatoms, which form important seasonal blooms (Treguer and Pondaven, 672000). Biologically-mediated biogenic opal dissolution has been observed to increase with organic 68matter degradation in surface waters (Bidle and Azam, 1999, 2001; Goutx et al., 2007) and to 69diminish with temperature decrease (Bidle et al., 2002) or hydrostatic pressure increase (Tamburini et 70al., 2006). Adding another ballast mineral $\left(\mathrm{CaCO}_{3}\right)$ to diatom aggregates diminished diatom aggregate 71remineralisation by zooplankton (Le Moigne et al., 2013). Regarding $\mathrm{CaCO}_{3}$, biologically-mediated 72dissolution has also been suggested (Antia et al., 2008; Harris, 1994; Jansen and Wolf-Gladrow, 2001; 73Milliman et al., 1999) to explain the fact that significant $\mathrm{CaCO}_{3}$ dissolution is occurring in the upper $741000 \mathrm{~m}$ of the water column above the calcite or aragonite saturation horizon (Wollast and Chou, 751998, 2001). However, there is still no or contradictory evidence that this dissolution could be 76microbiologically-mediated (Bissett et al., 2011), and the link between $\mathrm{CaCO}_{3}$ dissolution and $\mathrm{POC}$ 77degradation remains unclear.

780cean acidification experiments using diatom aggregates supplemented with $\mathrm{CaCO}_{3}$ ballast indicate 79that $\mathrm{CaCO}_{3}$ dissolution and $\mathrm{POC}$ degradation will potentially increase with increasing $\mathrm{pCO}_{2}$, a 80phenomenon that is exacerbated under increasing pressure (de Jesus Mendes and Thomsen, 2012). 81However, little is known about the biodegradation of calcifiers aggregates. Among the calcifiers, 82coccolithophorids contribute to air-sea $\mathrm{CO}_{2}$ exchange, through their combined photosynthesis (sink of $83 \mathrm{CO}_{2}$ ) and calcification (source of $\mathrm{CO}_{2}$ ) activities (Poulton et al., 2007). Coccolithophorid aggregates 84formation has been reported from many recent lab studies (Biermann and Engel, 2010; Chow et al., 852015; Engel et al., 2009a, 2009b; Iversen and Ploug, 2010), but they are considered as being more 86sensitive to fragmentation than diatom aggregates (De La Rocha and Passow, 2007).

87Laboratory biodegradation experiments using aggregates from the coccolithophore Emiliania huxleyi 88showed that heavily calcified strains have higher settling velocities and are better preserved over time 
89than poorly calcified strains (Engel et al., 2009a, 2009b). Oxygen consumption within E. huxleyi 90aggregates can be 4 to 7 times larger than that of marine snow and diatom aggregates, indicating that 91they may be more prone to degradation (Ploug et al., 2008). Nevertheless, the carbon-specific 92respiration rate per meter settled was found to be lower in E. huxleyi aggregates than in diatom 93aggregates of similar size (Iversen and Ploug, 2010). This potentially confers coccolithophorid 94aggregates a larger potential for transporting organic carbon deeper in the ocean relative to diatom 95aggregates. It is important to note that the biodegradation experiments cited above were conducted 96in the presence of culture-associated prokaryotes or natural prokaryotic assemblages stored for a 97long time before use and the effect of fresh natural prokaryotic assemblages remains to be assessed. 98In addition, the increase in pressure experienced by aggregates sinking through the water column has 99yet to be included in such experiments.

100The objective of the present study was therefore to investigate the effect of hydrostatic pressure on 101the lipid composition (an indicator of cell degradation) and $\mathrm{CaCO}_{3}$ dissolution within $\mathrm{E}$. huxleyi 102aggregates in the presence of fresh free-living natural prokaryotic assemblages collected at $200 \mathrm{~m}$ 103depth in the NW Mediterranean Sea. Incubations were performed under controlled pressure 104conditions simulating a sinking rate of $150 \mathrm{~m} \mathrm{~d}^{-1}$, in which we monitored the structure of the 105prokaryotic communities as well as the degradation of E. huxleyi lipids over 10 days following the 106experimental design presented in Tamburini et al. (2009). Total alkalinity, particulate inorganic and 107organic carbon (PIC and POC) and total organic carbon (TOC) concentrations were also monitored as 108indicators of $\mathrm{CaCO}_{3}$ dissolution and organic carbon remineralization.

\section{Results}

110Two sets of incubations (Exp A and Exp B) were performed at $13^{\circ} \mathrm{C}$, with two pressure conditions 111applied in parallel: constant atmospheric pressure (ATM) and increasing hydrostatic pressure 112corresponding to a sinking simulation from 200 to $1700 \mathrm{~m}$ depth (HP). The E. huxleyi aggregate 113dilutions in either sterile-filtered (Exp A) or fresh GF/F-filtered (Exp B) seawater were sampled at t0 
114and after 10 days in the incubation vessels (t10). Exp A was performed with sterile-filtered seawater

115to monitor the development of prokaryotes associated with the E. huxleyi culture, while Exp B was 116designed to observe the development on E. huxleyi aggregates of a natural freshly collected seawater 117free-living prokaryotic community, and its effect on the organic and inorganic carbon contents of the 118aggregates.

\section{Prokaryotic development}

120The prokaryotic abundance associated with E. huxleyi culture aggregates (Exp A) did not change 121significantly between the start (t0: $7.7 \pm 1.810^{3}$ cells $\mathrm{mL}^{-1}$, average $\pm \mathrm{SD}$ ) and end of the incubation 122(ATMt10: $6.5 \pm 0.210^{3}$ cells $\mathrm{mL}^{-1}$; HPt10: $9.4 \pm 3.9210^{3}$ cells $\mathrm{mL}^{-1}$ ). Normalizing cell concentrations by 123the total organic carbon (TOC) concentration measured in each replicate to account for potential 124 variations in the initial amount of aggregates added to each bottle, no significant difference was 125observed between both pressure conditions (Fig. 1A).

126In Exp B, the total prokaryotic abundance increased by two orders of magnitude after 10 days 127(ATMt10: $2.2 \pm 0.410^{6}$ cells $\mathrm{mL}^{-1}$, HPt10: $2.7 \pm 0.010^{6}$ cells $\mathrm{mL}^{-1}$ ), with no significant difference 128between pressure treatments, when normalised by TOC (Fig. 1A). The growth of prokaryotes attached 129to E. huxleyi aggregates was stimulated under increasing pressure incubation (HP), where large 130aggregates were observed at the end (Suppl. Fig. 1). In this condition, attached prokaryotes (> $2 \mu \mathrm{m})$ 131 were significantly more abundant $(35.9 \pm 14.7 \%$ of total DAPI positive cells) than under constant 132atmospheric pressure $(20.9 \pm 4.7 \%$, Mann-Whitney-MW $p<0.05)$.

133Under both atmospheric and increasing pressure conditions, abundances of Archaea and Bacteria 134 were two and three orders of magnitude higher than at t0, respectively. Although the proportion of 135Euryarchaea was 4.1 times lower under pressure (Fig. 1B, significant, MW $p<0.05$ ), increasing 136pressure had no effect on the proportion and abundance of Crenarchaea (ATMt10: $2.3 \pm 0.210^{4}$ cell 137 $\mathrm{mL}^{-1}, \mathrm{HPt10}: 2.6 \pm 0.410^{4} \mathrm{cell}^{-1} \mathrm{~mL}^{-1} \mathrm{MW} p=0.51$ ) and Bacteria (ATMt10: $1.3 \pm 0.210^{6} \mathrm{cell}^{-1} \mathrm{~mL}^{-1}, \mathrm{HPt} 10$ : $1381.4 \pm 0.210^{6}$ cell $\left.\mathrm{mL}^{-1}, \mathrm{MW} p=0.83\right)$. Among the Bacteria, Alpha- and Gamma-proteobacteria cell 
139concentrations increased by three orders of magnitude during the incubations, and the fraction of 140Alphaproteobacteria was twice as low in conditions of increasing HP than at ATM (not significant, $141 \mathrm{MW} p=0.13)$. The proportion of Bacteroidetes also tended to be on average 1.9 times lower in HP 142than in ATM conditions (not significant, MW $p=0.83$ ), but their concentrations increased only by one 143to two orders of magnitude.
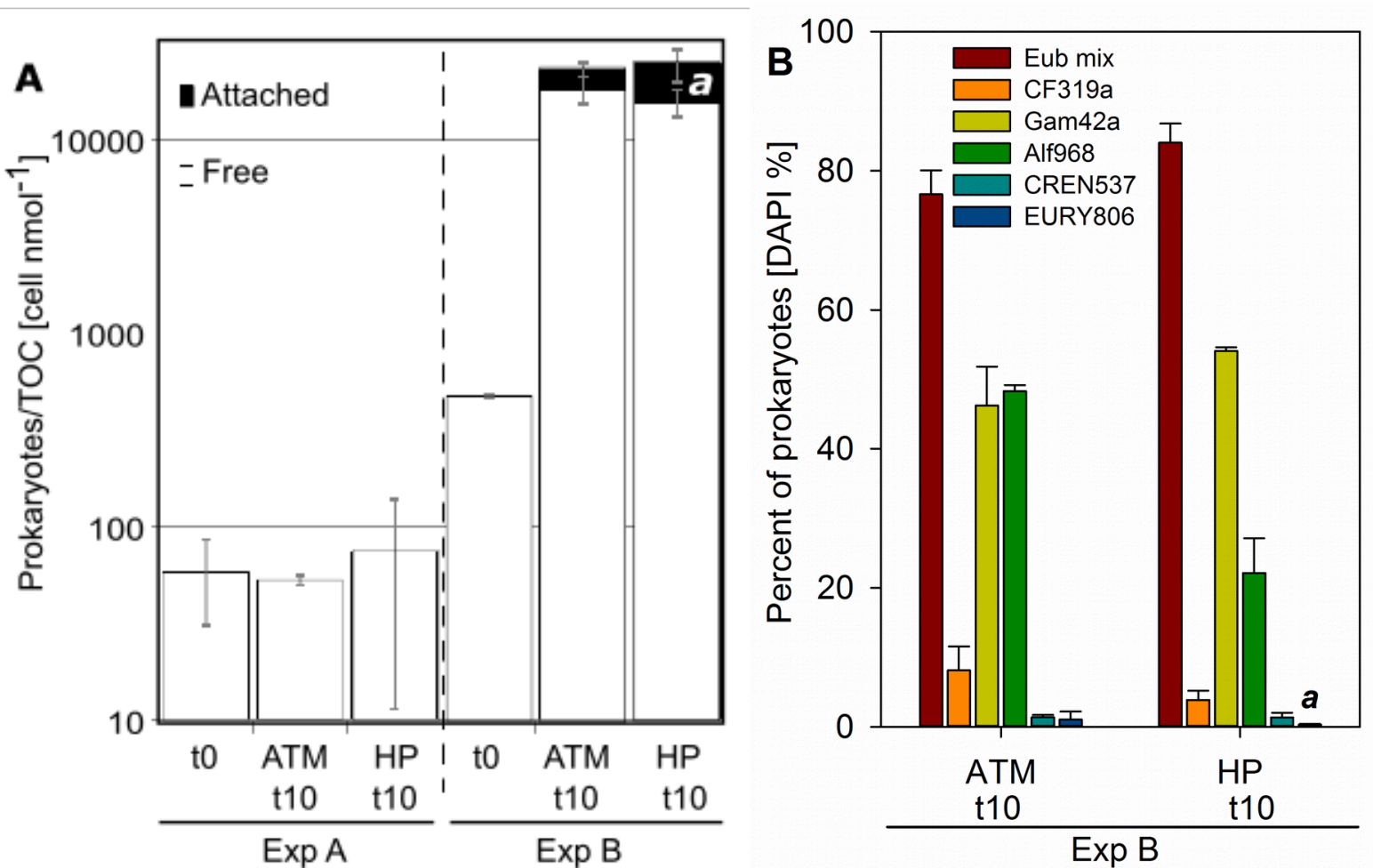

144

$\operatorname{Exp} \mathrm{A}$

Exp B

$\operatorname{Exp~B}$

145Figure 1: (A) Total prokaryotic abundance (DAPI-stained cells) normalized by sample TOC concentration in 146Emiliania huxleyi aggregates biodegradation Exp A (no natural prokaryotes added) and Exp B (GF/F-filtered 147 natural prokaryotic community added) initially (to) and after 10 days under constant atmospheric pressure 148(ATMt10) or increasing hydrostatic pressure (HPt10). White bars: free-living prokaryotes; Black bars: $>2 \mu \mathrm{m}$ 149particle-attached prokaryotes; (B) Percent of total prokaryotes (DAPI-stained cells) at the end of Exp B, 150detected by catalyzed reporter deposition coupled with fluorescence in situ hybridization (CARD-FISH). Eub 151mix (Eub338,Eub-II and Eub-III): Bacteria; CF319a: Bacteriodetes; Alf968, Gam42a: alpha- and gamma152subclasses of Proteobacteria; Cren537: Crenarchaea; Eury806: Euryarchaea. Average \pm SD. Significant differences 153between ATM and HP are indicated as $a$ (Mann-Whitney $p<0.05$ ) for particle-attached (A) or total prokaryotes 154(B).

\section{E. huxleyi detritus organic carbon content and lipid degradation}

156During the Exp B, TOC and particulate organic carbon (POC) concentrations tended to decrease over

157the 10 days incubation under atmospheric pressure only (Fig. 2A, ATMt10, not significant, $p=0.13$ ).

158The POC pigment content decreased significantly after 10 days of exposure to natural prokaryotic 
159assemblages, with no effect of pressure (Fig. 2B). In contrast, the lipid content (excluding pigments) 160decreased significantly in HPt10 but not in ATMt10 (Fig. 2C).
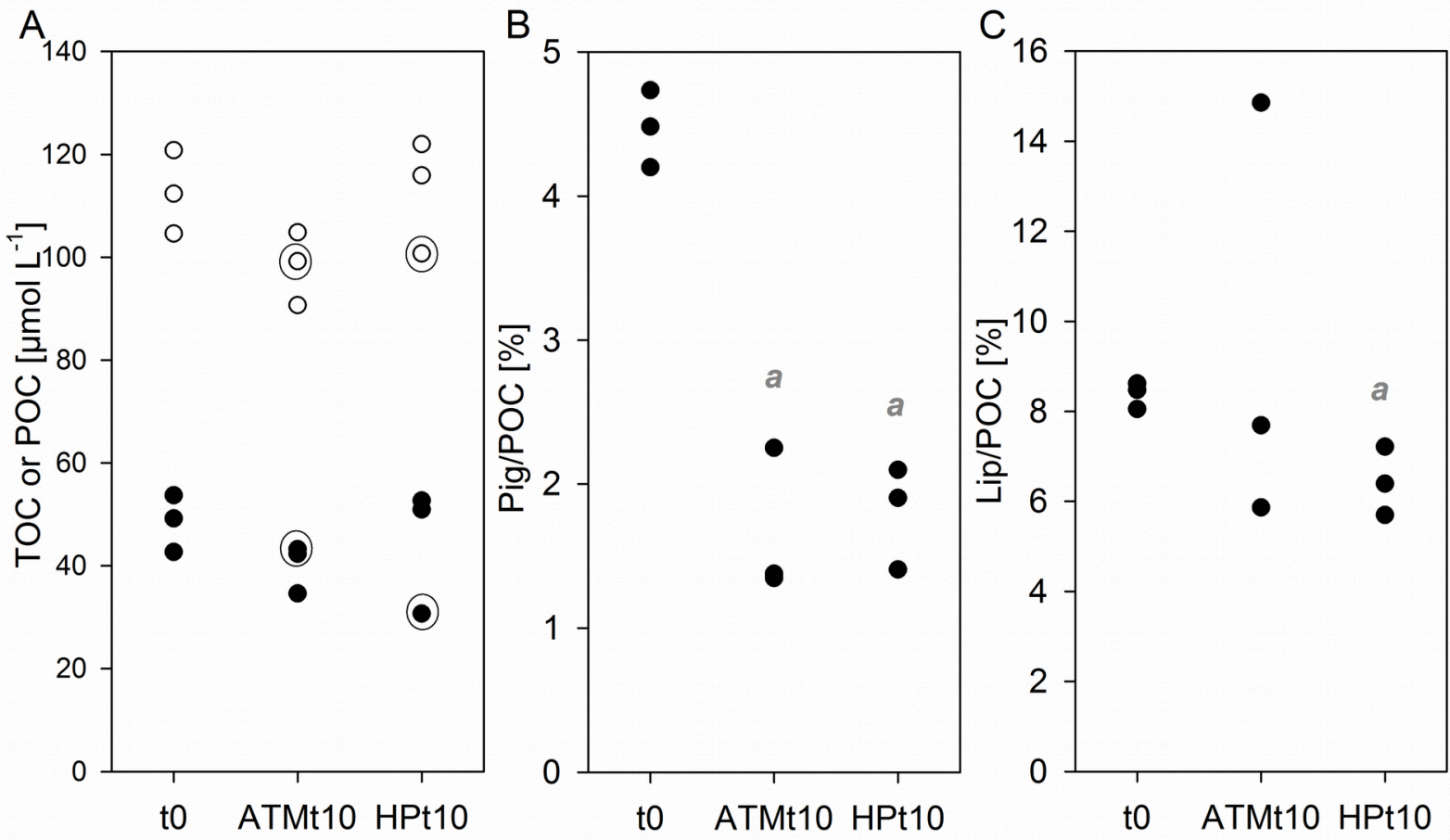

161

162Figure 2: Variation in organic carbon composition in Exp B: (A) total or particulate organic carbon (TOC-empty 163circles, or POC-filled circles, $\mu \mathrm{mol} \mathrm{L} \mathrm{L}^{-1}$ ), (B) POC pigment fraction (\%), (C) POC lipid fraction (pigments excluded, $164 \%$ ). Significant differences (Mann-Whitney $p<0.05$ ) are indicated as: $\boldsymbol{a}$ between t0 and t10. Circled data points 165belong to the same ATM and HP replicates circled in Fig. 4.

166At the start of Exp B, the lipid composition in E. huxleyi aggregates was similar to the one described in 167an earlier study with the same strain of E. huxleyi in exponential growth (Bell \& Pond, 1996; see 168suppl. Table 1). Overall, chloroplast lipids (including pigments and membrane monogalactosyl169diacylglycerol-MGDG) and cell membrane lipids (phospholipids) dominated the lipid composition 170(61.9-63.1\%). Sterols, hydrocarbons, neutral lipids (wax esters, triglycerides, methyl esters, ketones, 171free fatty acids and alcohols) and metabolites (degradation lipids: mono- and di-acylglycerols) 172accounted for $35.1-37.2 \%$ of the particle lipids.

173Within the non-pigment lipids, a significant decrease in the proportion of chloroplast membrane and 174whole cell membrane lipids (MGDG and PL, to 9.8-18.2 \% and 25.4-33.5 \%, respectively) was 175observed in both ATMt10 (2.5-6.8 \% and 4.8-6.8 \%) and HPt10 samples (0.0\% and 4.7-8.5 \%). 176Meanwhile, the proportion of hydrocarbons, methyl esters and ketones increased significantly in both 
177conditions (Fig. 3). HPt10 samples experienced significant losses of membrane sterols and MGDG 178relative to ATMt10 samples. At the same time, the relative proportion of reserve wax esters and 179triglycerides were significantly higher in HP (HP: 5.9-12.5 \%; ATM: 0.0-5.5 \%), mainly due to the 180appearance of triacylglycerides.

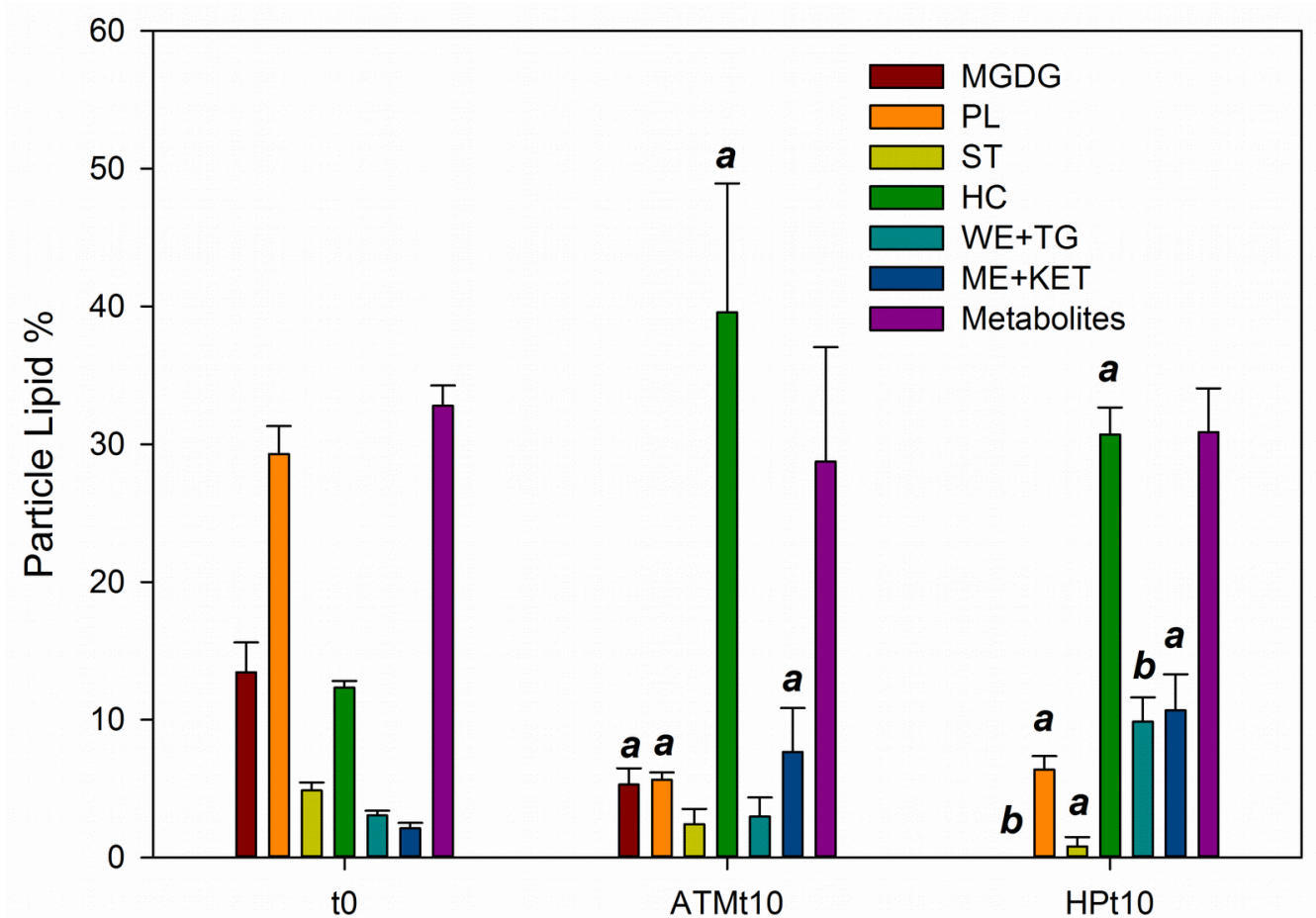

181

t0

ATMt10

HPt10

182Figure 3: Variation in the lipid composition of E. huxleyi detritus in Exp B: Proportions of the different lipids 183(pigments are excluded, \% $\mathrm{L}_{\text {tot }}$ ). MGDG: monogalactosyldiacylglycerol, PL: phospholipids, ST: sterols, HC: 184Hydrocarbons, WE+TG: wax esters and triglycerides, ME+KET: methyl esters and ketones, ; Average \pm SD. 185 Significant differences (Mann-Whitney $p<0.05$ ) are indicated as: $\boldsymbol{a}$ between t0 and t10, $\boldsymbol{b}$ between ATM and HP.

\section{Inorganic carbon content variations}

187A significant drop of particulate inorganic carbon (PIC, Fig. 4A) was observed in both ATM and HP 188conditions after $10 \mathrm{~d}(p<0.05)$. It was larger under HP than at ATM (not significant, $p=0.13$ ). Total 189alkalinity $\left(A_{T}\right)$ increased significantly between to and ATMt10 (Fig. 4B, $p<0.05$ ) but the increase was 190significantly lower under HP. The increase in $A_{T}$ observed between to and HPt10 was indeed not 191statistically significant $(p=0.27)$. 

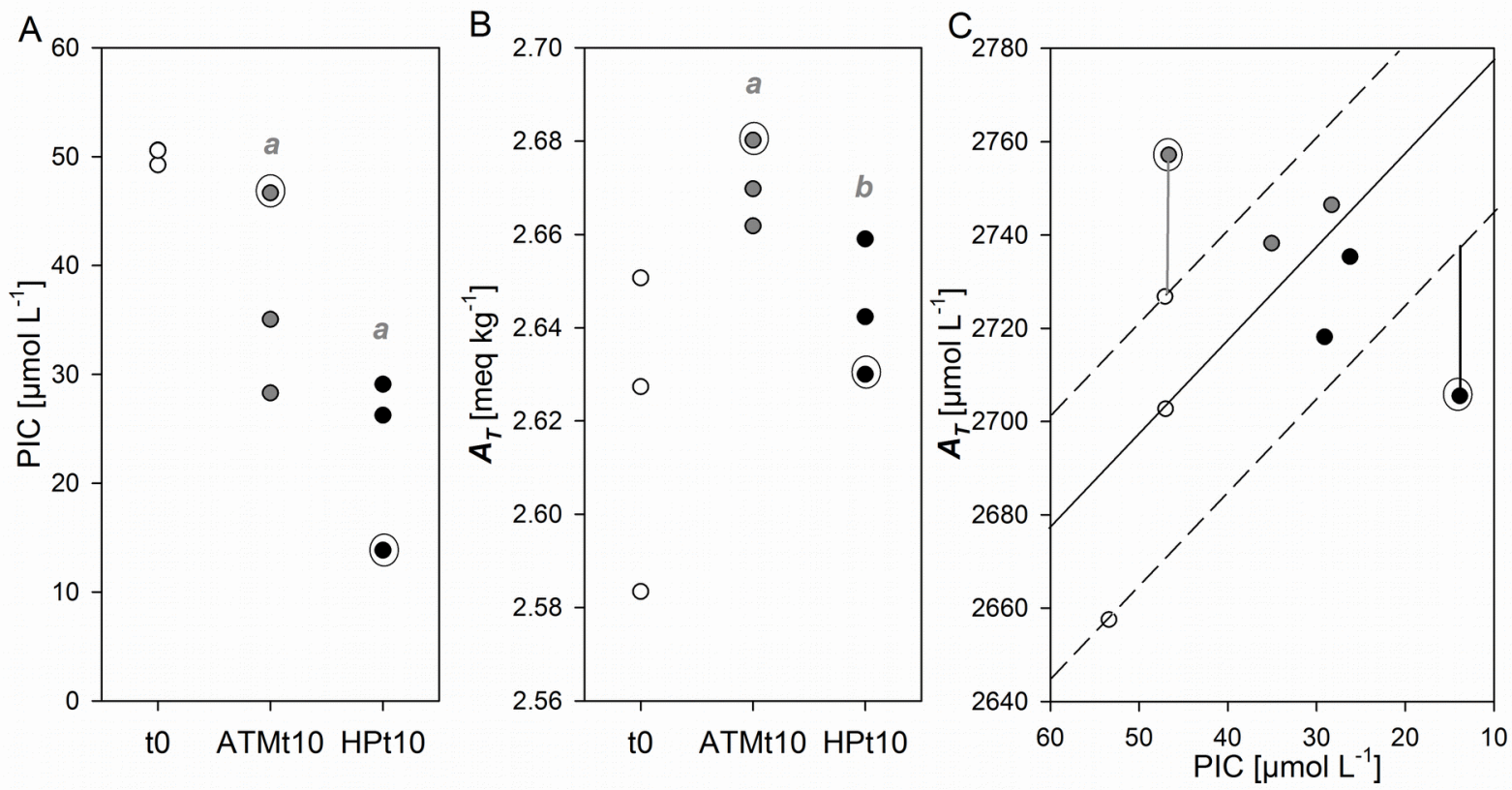

192

193Figure 4: Variation in (A) particulate inorganic carbon (PIC, $\left.\mu \mathrm{mol} \mathrm{L}^{-1}\right)$, (B) total alkalinity $\left(A_{T}\right.$, meq $\left.\mathrm{kg}^{-1}\right)$, and $(C)$ $194 A_{T}$ converted to $\mu \mathrm{mol} \mathrm{L}^{-1}$ (using a seawater density of $1028.7 \mathrm{k} \mathrm{kg}^{-1}$ ) vs PIC in Exp B. Full and dashed lines on 195panel $\mathrm{C}$ model the expected co-evolution of $A_{T}$ and PIC during calcite dissolution. Significant differences (Mann196Whitney $p<0.05$ ) are marked with an " $a$ " between to and t10, " $b$ " between ATM and HP. Circled data points 197point at the ATM2 and HP3 replicate incubations displaying values out of the expected range for calcite 198dissolution from the measured to values shown in panel $\mathrm{C}$.

\section{Discussion}

\section{Effect of hydrostatic pressure increase on the prokaryotic community}

201During the present E. huxleyi aggregate biodegradation experiment, initial natural mesopelagic 202Mediterranean Sea prokaryotic concentrations increased by up to two orders after 10 days in 203controlled temperature and hydrostatic pressure (HP) conditions simulating particle sinking from $204200 \mathrm{~m}$ to $1700 \mathrm{~m}$ depth at a rate of $150 \mathrm{~m} \mathrm{~d}^{-1}$. Such a high prokaryotic development has recently been 205observed with deep Mediterranean seawater natural prokaryotic communities amended with labile 206marine broth, both under atmospheric (ATM) and HP conditions (Wannicke et al., 2015). This might 207therefore indicate that $E$. huxleyi aggregates constitute a relatively labile substrate for mesopelagic 208Mediterranean prokaryotic communities to grow on.

209The natural prokaryotic diversity was dominated by Bacteria, with a lower proportion of Archaea at 210the end of the incubation, as previously observed in similar experiments (Tamburini et al., 2006, 
2112009), despite a significant increase in absolute abundance. The initial fraction of Bacteria, 212Crenarchaea and Euryarchaea were lower in the present experiment (30\%, $7 \%$ and $4 \%$, respectively) 213than in previous experiments with $200 \mathrm{~m}$ depth seawater sampled in different areas of the 214Mediterranean Sea (Tamburini et al., 2006, 2009). Different sea surface mixing conditions at the time 215of the natural prokaryotic community sampling for the different experiments might have resulted in 216different initial community compositions (Pinazo, pers. Com). When focusing on the classes of 217Bacteria generally found associated to marine aggregates (Acinas et al., 1999; Delong et al., 1993; 218Moeseneder et al., 2001; Ploug and Grossart, 1999; Simon et al., 2002; Thiele et al., 2015), only 219Bacteroidetes and Alphaproteobacteria tended to be sensitive to increasing hydrostatic pressure 220conditions (HP). Similar trends were observed during previous particle sinking simulation experiments 221with natural faecal pellets (Tamburini et al., 2009). The latter authors proposed that the sensitivity of 222Bacteroidetes to pressure may have reduced the amount of particulate carbohydrate hydrolysed. This 223could result in a lower production of dissolved carbohydrates as substrate for Alphaproteobacteria 224(Tamburini et al., 2009). A similar mechanism might be at play in the present experiment with $E$. 225huxleyi detritus, which is supported by the observation of large sticky particles and aggregates under 226HP condition only, as in Tamburini et al. (2009)(Suppl. Fig. 1). These large sticky aggregates might 227indeed be the result of less degradation of transparent exopolymeric particles (TEP) under HP relative 228to ATM (Tamburini et al., 2009), associated with the fact that more dissolved carbohydrates may have 229been released under HP by E. huxleyi, possibly resisting prokaryotic degradation (Nanninga and 230Tyrrell, 1996) and scavenged by TEP (Engel et al., 2004).

231 Interestingly, we observed that prokaryotes grew significantly more on $>2 \mu \mathrm{m}$ aggregates under 232increasing pressure (HP) than at atmospheric pressure (ATM). This pattern was not observed in a 233previous similar controlled experiment studying the biodegradation of natural aggregates collected in 234the Mediterranean Sea (mainly faecal pellets) during 6.5 days, although the formation of visible sticky 235aggregates had also been observed under HP (Tamburini et al., 2009). The fact that the present 236simulation lasted longer and reached higher pressure levels could explain that the pattern observed 
237here may not have been detected in the previous study. Finally, it also is also possible that 238coccolithophorid cells are more sensitive to pressure than faecal pellets or diatom aggregates 239(Tamburini et al., 2006, 2009). Hence, more labile intracellular organic matter would be released in 240the aggregates surroundings, favouring higher prokaryotic growth. To verify the latter hypothesis, we 241analysed the aggregate lipid contents and calculated a lipolysis index.

\section{Degradation of E. huxleyi aggregates organic matter}

243Assuming a prokaryotic cellular carbon content of 12.4-53.0 fg C cell ${ }^{-1}$ (Fukuda et al., 1998; Kogure 244and Koike, 1987), prokaryotes made up for $0.05-0.21 \%$ of the TOC at t0, which increased to $1.84-$ $24511.44 \%$ at ATMt10 and 2.32-11.94 \% at HPt10. Heterotrophic growth could have been supported by 246the dissolved organic matter present at the start of the incubation, and/or by the degradation of $E$. 247huxleyi aggregates. A lipolysis index defined as the ratio of metabolites resulting from acyl-lipid 248degradation to the sum of acyl lipids can be used to characterize the degradation stage of labile 249organic matter (Goutx et al., 2000, 2003). Although the lipid index in E. huxleyi aggregates increased 250significantly between the beginning (t0: $0.72 \pm 0.06$ ) and the end of the experiment (ATMt10: 2512.07 \pm 1.22 , HPt10: $1.93 \pm 0.32$ ), there was no significant pressure effect (MW $p=0.51$ ). However, the 252lipid fraction of E. huxleyi detritus organic carbon decreased significantly after ten days under HP, 253contrasting with previous observations using natural aggregates, mainly consisting in faecal pellets 254(Tamburini et al., 2009). In addition, compared to the lipid composition at ATM, membrane lipids 255(phospholipids, sterols, MGDG) disappeared from the particulate fraction significantly more under HP 256than at ATM, which could indicate higher E. huxleyi cell lysis under pressure (Baldi et al., 1997). E. 257huxleyi aggregates might therefore be more vulnerable to degradation under pressure than faecal 258pellets. 


\section{Changes in mineral content}

260Particulate inorganic carbon (PIC) decreased more under HP than at ATM, suggesting that more 261calcite dissolution may have occurred under increased hydrostatic pressure (Fig. 4). Enhanced PIC 262dissolution under HP has been observed in a previous study with diatom-mineral (carbonate263kaolinite-smectite) aggregates, together with a decreased POC decay rate (de Jesus Mendes and 264Thomsen, 2012). We here show that increased $\mathrm{CaCO}_{3}$ dissolution can occur in calcite-sheathed cell 265aggregates sinking through mesopelagic waters in the presence of natural prokaryotic communities.

266According to the stoichiometry of calcification, two moles of total alkalinity are produced per mole of $267 \mathrm{CaCO}_{3}$ dissolved (approximated as moles of PIC in Fig. 4C). However, although there was more calcite 268dissolution under pressure, the increase in total alkalinity was larger at atmospheric pressure. 269Nonetheless, values were within the range expected for calcite dissolution, considering the starting 270total alkalinity and PIC conditions (Fig. 4C), except for the two outliers circled in Fig. 4 (namely ATM2 271 and HP3 incubations, also circled in Fig. 2). Processes other than $\mathrm{CaCO}_{3}$ dissolution may explain the 272outlying PIC- $A_{T}$ pairs measured in replicates ATM2 and HP3, which respectively also displayed the 273lowest prokaryotic abundance $\left(1.7710^{6} \mathrm{cell} \mathrm{mL}^{-1}\right)$ and POC concentration $\left(30.7 \mu \mathrm{mol} \mathrm{L}^{-1}\right)$.

274Total alkalinity may indeed be affected by microbial aerobic and anaerobic organic matter 275remineralization/transformation through the consumption or release of ammonium, nitrate, 276phosphate and sulphate (Gattuso et al., 1999). The processes of respiration, nitrification and sulphate 277reduction have adverse effects on protons release/uptake. However, the difference of $+31 \mu \mathrm{mol} \mathrm{L}{ }^{-1} \boldsymbol{A}_{\mathrm{T}}$ 278between the value measured in ATM2 and the value expected from the triplicate t0 PIC 279concentrations cannot be solely explained by dissimilation of ammonium by organic matter 280respiration. This process would result in a $A_{\boldsymbol{T}}$ increase of 0.17 moles per mole of TOC respired (Gattuso 281et al., 1999), when the difference in TOC between t0 replicates and ATM2 was only 5.4 to $21.6 \mu \mathrm{mol}^{-}$ $282^{1}$ (which was comparable to the other 2 ATM replicates). Since the to replicates consisted in 283independent splits of the initial aggregate-seawater mixture that was further split into ATM and HP 284replicate incubations, another explanation for this outlying pair could be that the ATM2 incubation 
285may have started with a higher PIC concentration around $65 \mu \mathrm{M}$ (higher concentration of detached 286coccoliths).

287Similarly, the $-31 \mu \mathrm{mol} \mathrm{L}^{-1}$ difference in $A_{T}$ between the value measured in HP3 and the expected value 288 cannot be explained solely by the dissimilation of nitrate by organic matter respiration. Such a 289process would lead to a decrease in $A_{\boldsymbol{T}}$ of 0.13 moles per mol of $\mathrm{CO}_{2}$ released (Gattuso et al., 1999), 290whereas the difference in TOC concentration between t0 replicates and HP3 comparable to that with 291ATM2 was observed (Fig. 2). Given the large $\boldsymbol{A}_{\boldsymbol{T}}$ variability observed between the independent splits 292sampled at t0, it is more likely that the HP3 incubation started with a much lower $A_{T}$ than the other 293HP replicates (around $2635 \mu \mathrm{mol} \mathrm{L}^{-1}$, or $2561 \mu \mathrm{mol} \mathrm{kg}{ }^{-1}$ at $50 \mu \mathrm{M}$ PIC).

\section{Implications for the carbon pump and the ballast hypothesis}

295In the Mediterranean Sea, $\mathrm{CaCO}_{3}$-sheathed coccolithophores can dominate the phytoplankton 296community (Ignatiades et al., 2009). They are highly diverse, including large numbers of the 297ubiquitous species E. huxleyi (Cros and Fortuño, 2002; Knappertsbusch, 1993). Several studies have 298stressed the need for controlled experiments to validate the hypothesis that $\mathrm{CaCO}_{3}$ may be a more 299efficient POC "carrier" than biogenic silica (De La Rocha and Passow, 2007; Passow and De La Rocha, 3002006; Passow, 2004). Our experiment contributes to a better understanding of this issue. In contrast 301with previous experiments using natural marine snow/faecal pellets (Tamburini et al., 2009; Turley, 3021993), organo-mineral aggregates (de Jesus Mendes et al., 2007) or diatom culture aggregates (de 303Jesus Mendes and Thomsen, 2012; Tamburini et al., 2006), $\mathrm{CaCO}_{3}$-containing E. huxleyi culture 304aggregates appear more sensitive to the increase in hydrostatic pressure. Our results suggest that 305increased pressure results in higher cell lysis and $\mathrm{CaCO}_{3}$ dissolution relative to ATM. The protecting 306 effect of coccoliths may therefore not remain effective throughout the water column, since coccoliths 307 might detach from cells and dissolve more readily under pressure. Calcium carbonate may therefore 308not be an efficient POC carrier to the deep ocean in the form of intact coccolithophorid cells. 
309Coccolithophores are the main producers of the pelagic $\mathrm{CaCO}_{3}$ biogenically produced in the global 310ocean (0.8-1.4 Gt year ${ }^{-1}$ ) (Feely et al., 2004) and may contribute to about $50 \%$ of pelagic $\mathrm{CaCO}_{3}$ 311deposition in sediments (Broecker and Clark, 2009; Poulton et al., 2007). Yet, the processes and rates 312of coccolith $\mathrm{CaCO}_{3}$ dissolution in the upper layers of the ocean are poorly identified and quantified. 313Since calcification decreases the ocean $\mathrm{CO}_{2}$ uptake capacity by reducing total alkalinity, the depth of 314calcite dissolution likely has important implications on the net gradient in $\mathrm{pCO}_{2}$ between the ocean 315and atmosphere (Antia et al., 2001; Barrett et al., 2014).

316The dissolution of pelagic $\mathrm{CaCO}_{3}$ particles has long been assumed to occur primarily at great depths 317below the calcite and aragonite saturation depths (Broecker, 1977). In fact, up to $80 \%$ of the $\mathrm{CaCO}_{3}$ 318that is exported out of the surface ocean might actually dissolve in the upper $1000 \mathrm{~m}$, well above the 319lysocline (Chung et al., 2003; Feely et al., 2004; Iglesias-Rodriguez et al., 2002; Jansen and Wolf320Gladrow, 2001; Milliman et al., 1999; Wollast and Chou, 1998, 2001). Grazing by microzooplankton 321 has been shown to play an important role in coccolithophorid calcite dissolution (Antia et al., 2008; 322Harris, 1994; Jansen and Wolf-Gladrow, 2001; Milliman et al., 1999). In contrast, carbonate 323dissolution on individual calcifying cells by microbes was deemed negligible (Bissett et al., 2011), but 324the presence of chemical gradients within sinking aggregates (Ploug and Bergkvist, 2015) may create 325micro-environments with lower $\mathrm{pH}$ and calcite saturation state that could facilitate (a)biotic 326dissolution. We show here that calcium carbonate dissolution in the presence of natural prokaryotic 327communities might be higher under increasing hydrostatic pressure. Pressure was recently suggested 328to affect dissolution kinetics over and above its influence on the saturation constants (Dong et al., 3292016). The combined effect of pressure and microbial activities therefore remains to be assessed in a 330more mechanistic manner.

3310n the other hand, we show that increasing hydrostatic pressure potentially triggers the 332development of Mediterranean mesopelagic prokaryotic communities on E. huxleyi aggregates (as 333opposed to diatom detritus or natural aggregates, Tamburini et al., 2006, 2009), as well as 334aggregation. The study by Tamburini et al. (2009) had already shown that particulate 
335carbohydrates:POC and Transparent Exopolymer Particles (TEP):POC ratios could be significantly 336higher in conditions of increasing hydrostatic pressure. The prokaryotes themselves may promote 337aggregation, through the production of sticky extracellular muco-polysaccharides (Biddanda and 338Pomeroy, 1988; Biddanda, 1986; Turley, 1992). Moreover, coccoliths have been proposed as 339aggregation nuclei for colloidal DOM, therefore offering organic matter protection from 340solubilization/remineralization (Engel et al., 2009a). The increased aggregation observed under 341pressure in our reaction vessels could therefore compensate the loss of mineral ballast at depth, by 342increasing aggregate sizes and/or mineral scavenging potential. To what extent pressure-induced 343aggregation balances calcite dissolution in situ remains to be observed and assessed, by including 344model calculations, for instance.

\section{Methods}

\section{Production of Emiliania huxleyi aggregates and experimental design}

347The TW1 E. huxleyi strain (Algobank-Caen) was maintained in exponential growth phase in $\mathrm{K} / 2$ 348 medium (Keller et al., 2007) at $21^{\circ} \mathrm{C}$, under a 12-12h light-dark cycle (intensity: 4300 Lux). The culture 349was supplemented with Provasoli's antibiotic concentrate (3\% final concentration, Sigma) until the 350bacterial numbers reached a minimal proportion of one to two prokaryote per phytoplankton cell. 351The antibiotic solution was then removed for two culture passagings before E. huxleyi cells in 352exponential phase were concentrated by centrifugation (3000 rpm, $15 \mathrm{~min}$ ) (Houdan et al., 2005; 353Sawada and Shiraiwa, 2004). Fresh detritus was obtained according to a procedure modified from 354(Tamburini et al., 2006) by exposing cell culture to $55^{\circ} \mathrm{C}$ for $10 \mathrm{~min}$ only, which avoided cell disruption 355observed during freeze-thaw cycles. The detritus aliquots were immediately diluted in sterile-filtered 356or GF/F-filtered Mediterranean Seawater (for Exp A and Exp B, respectively, see details below) to 357reach a final concentration of about $600 \mu \mathrm{g} \mathrm{POC} \mathrm{L}{ }^{-1}$ (cell density of 5000 cell mL $^{-1}$ ) close to natural 358coccolithophore bloom (Holligan et al., 1993). Aliquots were sampled the starting point of the 359incubations (t0) for the various microbiological and chemical parameters described below. 


\section{Incubation in the PArticle Sinking Simulator (PASS)}

361The two experiments (Exp A and Exp B) were conducted in March 2007 using Mediterranean 362 seawater $\left(13^{\circ} \mathrm{C}\right)$ collected at $200 \mathrm{~m}$ depth, above the Marseilles Trench $\left(43^{\circ} 01^{\prime} 48 \mathrm{~N}-05^{\circ} 11^{\prime} 158 \mathrm{E}\right.$, $363600 \mathrm{~m}$ bottom depth). In Exp A, seawater was left in the dark at $4{ }^{\circ} \mathrm{C}$ for $15 \mathrm{~d}$ and gently filtered 364through $0.2 \mu \mathrm{m}$-porosity polycarbonate filters to subtract the prokaryotic community. In Exp B, fresh 365 natural prokaryotic assemblages $<0.7 \mu \mathrm{m}$ were recovered in the filtrate of a gentle filtration onto pre366combusted GF/F filters of the freshly collected seawater sample.

367Exp A and Exp B were incubated for $10 \mathrm{~d}$ at in situ temperature $\left(13^{\circ} \mathrm{C}\right)$. The PASS system was used 368following a procedure described in (Tamburini et al., 2009), except a peristaltic liquid dispenser 369(Jencons Scientific Ltd.) was used to obtain homogeneous replicate aliquots. Aliquots were incubated 370in $500 \mathrm{~mL}$ high-pressure bottles (HPBs) where pressure increased linearly using a piloted pressure 371generator in order to reproduce the increase in pressure that occurs when particles sink. 372Coccolithophores detritus was kept in suspension by regular half-revolutions of the HPBs in water 373baths kept at in situ temperature (Tamburini et al., 2006). For Exp A, two duplicate HPBs were kept at 374atmospheric pressure and two duplicate HPBs were exposed to increasing pressure (1.5 $\mathrm{MPa} \mathrm{d}^{-1}$ 375 corresponding to a sinking rate of $150 \mathrm{~m} \mathrm{~d}^{-1}$ ). This is applicable to mid-density particles, as discussed 376in (Tamburini et al., 2006) and corresponds to sinking rates observed in previous E. huxleyi aggregates 377studies (Engel et al., 2009b; Iversen and Ploug, 2010; Ploug et al., 2008). Exp B was performed with 378triplicate HPBs. After 10 days of incubation (HPt10, corresponding to a depth of $1700 \mathrm{~m}$ ), the 379pressurised coccolithophores detritus dilutions were decompressed and sampled as described in 380(Tamburini et al., 2009) for the parameters described below.

\section{Microbiological analyses}

382Samples for prokaryotic abundances $(50-135 \mathrm{~mL}$ ) were fixed using $0.2-\mu \mathrm{m}$ filtered formaldehyde ( $2 \%$ 383final concentration), kept at room temperature for $15 \mathrm{~min}$, and subsequently stored at $4^{\circ} \mathrm{C}$ in the dark 384 for around $12 \mathrm{~h}$. For total $(>0.2 \mu \mathrm{m})$ and free-living $(0.2-2.0 \mu \mathrm{m})$ prokaryotic abundances, samples 
385 were filtered onto $0.2-\mu \mathrm{m}$-pore-size polycarbonate filters supported by $0.45-\mu \mathrm{m}$-pore-size cellulose 386nitrate filters directly, or after filtration by gravitation onto $2.0-\mu \mathrm{m}$-pore-size polycarbonate filters, as 387in (Tamburini et al., 2009). Cells were stained with diamidinophenylindole (DAPI) according to (Porter 388and Feig, 1980). The fraction of "attached" or large prokaryotes $>2 \mu \mathrm{m}$ was calculated by subtracting 389values of the $0.2-2.0 \mu \mathrm{m}$ fraction from the total fraction.

390Samples for catalyzed reporter deposition coupled with fluorescence in situ hybridization (CARD-FISH) 391were treated as in (Tamburini et al., 2009): briefly, samples were filtered onto 0.2- $\mu \mathrm{m}$-pore-size 392polycarbonate filters as for the total prokaryotic abundances. Filters were washed twice with $0.2-\mu \mathrm{m}$ 393filtered MilliQ water, air-dried, and stored in scintillation tubes at $-20^{\circ} \mathrm{C}$ until analysis. Cells were $394 \mathrm{embedded}$ in low-gelling point $0.1 \%$ agarose (Sigma), dried at $37^{\circ} \mathrm{C}$ for $10 \mathrm{~min}$, and dehydrated with $39595 \%$ ethanol. Bacterial cell walls were permeabilized by subsequent treatments with lysozyme (10 mg 396 $\mathrm{ml}^{-1}$, Sigma)(Amann et al., 1995) and with achromopeptidase (60 U, Sigma)(Sekar et al., 2003). 397Archaeal cell walls were permeabilized with proteinase $\mathrm{K}\left(0.2 \mathrm{ml} \mathrm{ml}^{-1}\right.$, Fluka)(Teira et al., 2004). Acid 398treatment in $0.01 \mathrm{M} \mathrm{HCl}$ was performed to denature endogenous peroxydase before hybridization 399with the horseradishperoxydase (HRP)-labeled oligonucleotide probes listed in Table1: for a detailed 400protocol see (Tamburini et al., 2009). The filter portions hydridized with each probe were mounted in 401a Citifluor:Vectashield:DAPI mix, and DAPI and CARD-FISH-stained cells were quantified under an 402Olympus BX61 microscope equipped with a 100-WHg-lamp and appropriate filter sets according to 403(Tamburini et al., 2009).

404Table 1: 16S rRNA-targeted oligonucleotide probes used in this study.

\begin{tabular}{|l|l|l|c|c|}
\hline Probe & Sequence(5'-3') & Target organisms & $\begin{array}{l}\% \\
\text { Formamide }\end{array}$ & References \\
\hline Eub338/I & GCT GCCTCCCGTAGGAGT & Domain ofbacteria & 55 & (Amann et al., 1990) \\
\hline Eubll & GCA GCCACCCGTAGGTGT & Domain ofbacteria & 55 & (Daims et al., 1999) \\
\hline EubIII & GCT GCCACCCGTAGGTGT & Domain ofbacteria & 55 & (Daims et al., 1999) \\
\hline ALF968 & GGTAAGGTTCTGCGCGTT & $\begin{array}{l}\text { Most of Alfa of } \\
\text { Proteobacteria }\end{array}$ & 55 & (Manz et al., 1992) \\
\hline GAM42a ${ }^{a}$ & GCC TTCCCACATCGTTT & $\begin{array}{l}\text { Gamma-Subclass of } \\
\text { Proteobacteria }\end{array}$ & 55 & (Manz et al., 1992) \\
\hline CF319a & TGGTCCGTGTCTCAGTAC & $\begin{array}{l}\text { Cytophaga- } \\
\text { Flavobacter cluster }\end{array}$ & 55 & (Manz et al., 1996) \\
\hline
\end{tabular}




\begin{tabular}{|l|l|l|l|c|}
\hline Cren537 & TGACCACTTGAGGTGCTG & Crenarchaea & 20 & (Teira et al., 2004) \\
\hline Eury806 & CACAGCGTTTACACCTAG & Euryarchaea & 20 & (Teira et al., 2004) \\
\hline NegControl & TAGTGACGCGCTCGA & $\begin{array}{l}\text { For non-specific } \\
\text { probe binding }\end{array}$ & 55 & (Karner and Fuhrman, 1997) \\
\hline
\end{tabular}

$405^{\text {a }}$ Including an unlabeled competitor probe BET42a (5'-GCCTTCCCACTTCGTTT-3'), see (Manz et al., 1992) for 406details.

407

\section{Chemical analyses}

409All glassware was pre-combusted before use. Additionally, glassware was rinsed with $1 \mathrm{~N} \mathrm{HCl}$ and 410Milli-Q water after each sample. All plastic ware was rinsed with $1 \mathrm{~N} \mathrm{HCl}$ and Milli-Q water and 411changed for each sample. Sample aliquots for particulate organic carbon (POC, 50-104 mL) and lipids 412(P-lips, 140-500mL) were filtered onto pre-combusted $0.7 \mu \mathrm{m} \mathrm{GF/F} \mathrm{filters} \mathrm{(} 25 \mathrm{~mm}$ filter diameter) 413under a low vacuum $(<50 \mathrm{~mm} \mathrm{Hg})$ and preserved at $-20^{\circ} \mathrm{C}$ or in liquid nitrogen, respectively.

414Filters for particulate total carbon (PtotC) and POC were divided in two and analyzed as in Raimbault 415et al. (2008). The filter portions used for PtotC were analyzed directly, while filter portions for POC 416measurement were acidified with $100 \mu \mathrm{L} \mathrm{H}_{2} \mathrm{SO}_{4}(0.5 \mathrm{~N})$ and subsequently analyzed using high 417 combustion $\left(1000^{\circ} \mathrm{C}\right)$ on a mass spectrometer ( $\mathrm{CN}$-Integra tracer-mass). The concentration of 418particulate inorganic carbon (PIC) was calculated from the difference between PtotC and POC.

419Lipids were extracted from filters using a Bligh and Dyer (1959) protocol, and lipid classes were 420separated on chromarods and quantified on a thin layer chromatography/flame ionization detection 421(TLC/FID) latroscan apparatus model MK-6s (latron,Tokyo) coupled to a PC equipped with a Chromstar 4226.1 integration system (Bionis, Paris), as in Goutx et al. (2007). The separation of the 16 following lipid 423classes was obtained: neutral lipids including hydrocarbons $(\mathrm{HC})$, sterol esters co-eluting with wax 424esters (WE), ketones (KET), triacylglycerols (TG), free fatty acids (FFA), alcohols (ALC), sterols and 425diglycerides (DG); chloroplast lipids containing pigments (Pig), glycolipids and 426monogalactosyldiacylglycerol (MGDG); monoacylglycerols (MG); and phospholipids (PL) including 427diphosphatidylglycerides co-eluting with phosphatidylglycerides (DPG+PG), phosphatidylethanol428amine (PE) and phosphatidylcholine (PC). A lipolysis index was calculated as in Goutx et al. (2000, 
4292003), defined as the ratio of the sum of the metabolites (DG, MG, FFA, ALC) to the sum of the intact 430acyl-lipids (TG, PE, PI, DPG+PG, PC, WE, MGDG).

431TOC concentrations were obtained by adding POC to DOC values. Samples for DOC were obtained and 432preserved as in Tamburini et al. (2009). The DOC measurements were carried out in the laboratory at 433the Pisa section of the Institute of Biophysics (IBF), CNR, with a Shimadzu TOC-VCSN. Samples were 434acidified with $2 \mathrm{~N} \mathrm{HCl}$ and sparged for 3 minutes with $\mathrm{CO}_{2}$-free ultra-high purity air in order to remove 435inorganic carbon. From 3 to 5 replicate injections were performed until the analytical precision was 436lower than $1 \%$. The system blank was measured every day at the beginning and the end of analyses 437using low-carbon water $\left(2-3 \mu \mathrm{mol} \mathrm{L}^{-1} \mathrm{C}\right)$ produced by a Milli-Q system. Measurement reliability was 438assessed twice a day by comparison of data with DOC Consensus Reference Waters (CRM; Hansell, 4392005) (measured concentration $=42.7 \mu \mathrm{mol} \mathrm{L}^{-1}$, nominal concentration: $41-44 \mu \mathrm{mol} \mathrm{L} \mathrm{L}^{-1}$ ). For further 440analytical details refer to Santinelli et al. (2013)

441Samples for total alkalinity $\left(\boldsymbol{A}_{\mathrm{T}}\right)$ were filtered on GF/F membranes (duplicate $50 \mathrm{~mL}$ filtrate aliquots 442from the PtotC and POC GF/F filtrations), immediately poisoned with $100 \mu$ of a $50 \%$ saturated $\mathrm{HgCl}_{2}$ 443solution (37 $\mathrm{g} \mathrm{HgCl}_{2}$ in $1 \mathrm{~L}$ distilled water) and stored at $4^{\circ} \mathrm{C}$ in the dark pending analysis. $A_{\mathrm{T}}$ was 444determined on $20 \mathrm{~mL}$ subsamples using a home-made titration system composed of a $20 \mathrm{~mL}$ open 445temperature-controlled titration cell (kept at $25.0^{\circ} \mathrm{C}$ ), an Orion $8103 \mathrm{SC} \mathrm{pH}$ electrode calibrated on the 446National Bureau of Standards scale and a computer-driven Metrohm 665 Dosimat titrator, 447Switzerland. The seawater samples and the acid titrant $(0.1 \mathrm{~N} \mathrm{HCl})$ were kept at a constant 448temperature of $25^{\circ} \mathrm{C}$. Samples were weighted with a precision of $0.01 \mathrm{~g}$ before the titration to 449determine their exact volume from temperature and salinity. $A_{T}$ was calculated from a Gran function 450applied to $\mathrm{pH}$ variations from 4.2 to 3.0 as a function of added volume of $\mathrm{HCl}$. $A_{T}$ measurements had a 451reproducibility of $3 \mu \mathrm{mol} \mathrm{kg}$. 


\section{Statistical analyses}

453Differences in prokaryotic abundances ( $N=3$ replicate incubation bottles per condition) were 454analyzed by the non-parametric pairwise Mann-Whitney test on raw data (i.e. individual replicate 455values), due to the low number of replicates, using the Statistica 6 software. Unless otherwise stated, 456data are reported as averages and standard deviation (SD) and statistical difference was accepted at $p$ $457 \leq 0.05$

\section{Acknowledgements}

459Thanks are due to M.-D. Pizay for performing the determination of total alkalinity, to C. Pinazo for her 460insights on the hydrological conditions at the sampling location, and the crew of the N/O Antedon for 461assitance in the field. I. This work is a contribution to the Mediterranean Institute of Oceanography 462"AT-EMBE", and to the Labex OT-Med (ANR-11-LABEX-0061, www.otmed.fr) funded by the 463Investissements d'Avenir, French Government project of the French National Research Agency (ANR, 464www.agence-nationale-recherche.fr) through the $A^{*}$ Midex project (ANR-11-IDEX-0001-02), funding 465Virginie Riou during preparation of the manuscript.

\section{References}

467Acinas, S. G., Antón, J. and Rodríguez-Valera, F.: Diversity of free-living and attached bacteria in 468offshore Western Mediterranean waters as depicted by analysis of genes encoding $16 \mathrm{~S}$ rRNA, Appl. 469Environ. Microbiol., 65(2), 514-22 [online] Available from:

470http://www.pubmedcentral.nih.gov/articlerender.fcgi?

471 artid=91055\&tool=pmcentrez\&rendertype=abstract, 1999.

472Amann, R. I., Krumholz, L. and Stahl, D.: Fluorescent-oligonucleotide probing of whole cells for 473determinative, phylogenetic, and environmental studies in microbiology, J. Bacteriol., 172(2), 762474770 [online] Available from: http://www.pubmedcentral.nih.gov/articlerender.fcgi?

475artid=208504\{\&\}tool=pmcentrez $\{\&\}$ rendertype=abstract, 1990. 
476Amann, R. I., Ludwig, W. and Schleifer, K. H.: Phylogenetic identification and in situ detection of 477individual microbial cells without cultivation, Microbiol. Rev., 59(1), 143-169 [online] Available from: 478http://www.pubmedcentral.nih.gov/articlerender.fcgi?

479artid=239358 $\{\&\}$ tool=pmcentrez $\{\&\}$ rendertype=abstract, 1995.

480Antia, A. N., Koeve, W., Fischer, G., Blanz, T., Schulz-Bull, D., Scholten, J., Neuer, S., Kremling, K., Kuss, 481J., Peinert, R., Hebbeln, D., Bathmann, U., Conte, M., Fehner, U. and Zeitzschel, B.: Basin-wide 482particulate carbon flux in the Atlantic Ocean: Regional export patterns and potential for atmospheric 483CO2 sequestration, Global Biogeochem. Cycles, 15(4), 845-862, doi:10.1029/2000GB001376, 2001. 484Antia, A. N., Suffrian, K., Holste, L., Müller, M. N., Nejstgaard, J. C., Simonelli, P., Carotenuto, Y. and 485Putzeys, S.: Dissolution of coccolithophorid calcite by microzooplankton and copepod grazing, 486Biogeosciences Discuss., 5(1), 1-23 [online] Available from: https://hal.archives-ouvertes.fr/hal48700297955/, 2008.

488Armstrong, R. A., Lee, C., Hedges, J. I., Honjo, S. and Wakeham, S. G.: A new, mechanistic model for 489organic carbon fluxes in the ocean based on the quantitative association of POC with ballast minerals, 490Deep Sea Res. Part II Top. Stud. Oceanogr., 49(1-3), 219-236, doi:10.1016/S0967-0645(01)00101-1, 4912001.

492Baldi, F., Minacci, A., Saliot, A., Mejanelle, L., Mozetic, P., Turk, V. and Malej, A.: Cell lysis and release 493of particulate polysaccharides in extensive marine mucilage assessed by lipid biomarkers and 494molecular probes, Mar. Ecol. Prog. Ser., 153, 45-57, doi:10.3354/meps153045, 1997. 495Barrett, P. M., Resing, J. A., Buck, N. J., Feely, R. A., Bullister, J. L., Buck, C. S. and Landing, W. M.: 496Calcium carbonate dissolution in the upper $1000 \mathrm{~m}$ of the eastern North Atlantic, Global Biogeochem. 497Cycles, 28(4), 386-397, doi:10.1002/2013GB004619, 2014.

498Bell, M. V. and Pond, D.: Lipid composition during growth of motile and coccolith forms of Emiliania 499huxleyi, Phytochemistry, 41(2), 465-471, doi:10.1016/0031-9422(95)00663-X, 1996.

500Biddanda, B. A.: Structure and function of marine microbial aggregates, Oceanol. acta, 9(2), 209-211, 5011986. 
502Biddanda, B. A. and Pomeroy, L.: Microbial aggregation and degradation of phytoplankton-derived 503detritus in seawater: 1. Microbial succession., Mar Ecol Progr Ser 42, 79-88 [online] Available from: 504http://www.jourlib.org/references/11414368, 1988.

505Bidle, K. D. and Azam, F.: Accelerated dissolution of diatom silica by marine bacterial assemblages, 506Nature, 397, 508-512, 1999.

507Bidle, K. D. and Azam, F.: Bacterial control of silicon regeneration from diatom detritus: Significance of 508bacterial ectohydrolases and species identity, Limnol. Oceanogr., 46(7), 1606-1623, 509doi:10.4319/lo.2001.46.7.1606, 2001.

510Bidle, K. D., Manganelli, M. and Azam, F.: Regulation of oceanic silicon and carbon preservation by 511temperature control on bacteria, Science, 298(5600), 1980-1984, doi:10.1126/science.1076076, 5122002.

513Biermann, A. and Engel, A.: Effect of $\mathrm{CO}_{2}$ on the properties and sinking velocity of aggregates of the 514coccolithophore <I>Emiliania huxleyi</|>, Biogeosciences, 7(3), 1017-1029, doi:10.5194/bg-7-10175152010, 2010.

516Bissett, A., Neu, T. R. and Beer, D. de: Dissolution of calcite in the twilight zone: bacterial control of 517dissolution of sinking planktonic carbonates is unlikely, PLoS One, 6(11), e26404, 518doi:10.1371/journal.pone.0026404, 2011.

519Broecker, W. and Clark, E.: Ratio of coccolith CaCO3 to foraminifera CaCO3 in late Holocene deep sea 520sediments, Paleoceanography, 24(3), PA3205, doi:10.1029/2009PA001731, 2009.

521Broecker, W. S.: Recommendations of the working group on carbonate dissolution, in The fate of fossil 522 fuel $\mathrm{CO} 2$ in the oceans. Proceedings of a symposium conducted by the Ocean Science and Technology 523Division of the Office of Naval Research...held at the University of Honolulu, Hawaii, January 16-20, 5241976, edited by N. R. Andersen and A. Malahoff, pp. 207-212, New York Plenum Press., 1977. 525Buesseler, K. O. and Boyd, P. W.: Shedding light on processes that control particle export and flux 526attenuation in the twilight zone of the open ocean, Mar. Chem., 54(4), 1210-1232, 2009.

527Cardinal, D., Dehairs, F., Cattaldo, T. and André, L.: Geochemistry of suspended particles in the 
528Subantarctic and Polar Frontal zones south of Australia: Constraints on export and advection

529processes, J. Geophys. Res. Ocean., 106(C12), 31637-31656, doi:10.1029/2000JC000251, 2001.

530Cardinal, D., Savoye, N., Trull, T. W., André, L., Kopczynska, E. E. and Dehairs, F.: Variations of carbon 531remineralisation in the Southern Ocean illustrated by the Baxs proxy, Deep Sea Res. Part I Oceanogr. 532Res. Pap., 52(2), 355-370, doi:10.1016/j.dsr.2004.10.002, 2005.

533Cho, B. C. and Azam, F.: Major role of bacteria in biogeochemical fluxes in the ocean's interior, Nature, 534332(6163), 441-443, doi:10.1038/332441a0, 1988.

535Chow, J. S., Lee, C. and Engel, A.: The influence of extracellular polysaccharides, growth rate, and free 536coccoliths on the coagulation efficiency of Emiliania huxleyi, Mar. Chem., 175, 5-17, 537doi:10.1016/j.marchem.2015.04.010, 2015.

538Chung, S.-N., Lee, K., Feely, R. A., Sabine, C. L., Millero, F. J., Wanninkhof, R., Bullister, J. L., Key, R. M. 539and Peng, T.-H.: Calcium carbonate budget in the Atlantic Ocean based on water column inorganic 540carbon chemistry, Global Biogeochem. Cycles, 17(4), n/a-n/a, doi:10.1029/2002GB002001, 2003. 541Cros, L. and Fortuño, J. M.: Atlas of Northwestern Mediterranean Coccolithophores, Sci. Mar., 66, 1542182, doi:10.3989/scimar.2002.66s11, 2002.

543Daims, H., Brühl, A., Amann, R., Schleifer, K.-H. and Wagner, M.: The Domain-specific Probe EUB338 is 544insufficient for the Detection of all Bacteria : Development and Evaluation of a more Comprehensive 545Probe Set, Syst. Appl. Microbiol., 22, 434-444, 1999.

546Delong, E. F., Franks, D. G. and Alldredge, A. L.: Phylogenetic diversity of aggregate-attached vs. free547living marine bacterial assemblages, Limnol. Oceanogr., 38(5), 924-934, 548doi:10.4319/lo.1993.38.5.0924, 1993.

549Dong, S., Subhas, A., Berelson, W., Adkins, J. and Rollins, N.: Kinetics of Inorganic Calcite Dissolution in 550Seawater under Pressure, in Ocean Sciences Meeting, New Orleans, p. AH14A-0012. [online] 551Available from: https://agu.confex.com/agu/os16/preliminaryview.cgi/Paper88301.html, 2016. 552Ducklow, H. W., Steinberg, D. K. and Buesseler, K. O.: Upper ocean carbon export and the biological 553pump, Oceanography, 14(4), 50-58, doi:10.5670/oceanog.2001.06, 2001. 
554Engel, A., Thoms, S., Riebesell, U., Rochelle-Newall, E. and Zondervan, I.: Polysaccharide aggregation 555as a potential sink of marine dissolved organic carbon, Nature, 428(6986), 929-32, 556doi:10.1038/nature02453, 2004.

557Engel, A., Abramson, L., Szlosek, J., Liu, Z., Stewart, G., Hirschberg, D. and Lee, C.: Investigating the 558effect of ballasting by $\mathrm{CaCO} 3$ in Emiliania huxleyi, II: Decomposition of particulate organic matter, 559Deep Sea Res. Part II Top. Stud. Oceanogr., 56(18), 1408-1419, doi:10.1016/j.dsr2.2008.11.028, 5602009a.

561Engel, A., Szlosek, J., Abramson, L., Liu, Z. and Lee, C.: Investigating the effect of ballasting by CaCO3 562in Emiliania huxleyi: I. Formation, settling velocities and physical properties of aggregates, Deep Sea 563Res. Part II Top. Stud. Oceanogr., 56(18), 1396-1407, doi:10.1016/j.dsr2.2008.11.027, 2009b.

564Eppley, R. W. and Peterson, B. J.: Particulate organic matter flux and planktonic new production in the 565deep ocean, Nature, 282, 677-680, doi:10.1038/282677a0, 1979.

566Feely, R. A., Sabine, C. L., Lee, K., Berelson, W., Kleypas, J., Fabry, V. J. and Millero, F. J.: Impact of 567anthropogenic $\mathrm{CO} 2$ on the $\mathrm{CaCO} 3$ system in the oceans, Science, 305(5682), 362-366,

568doi:10.1126/science.1097329, 2004.

569Francois, R., Honjo, S., Krishfield, R. and Manganini, S.: Factors controlling the flux of organic carbon 570to the bathypelagic zone of the ocean, Glob. Biogeochem. Cycles, 16(4), 1087,

571doi:10.1029/2001gb001722, 2002.

572Fukuda, R., Ogawa, H., Nagata, T. and Koike, I.: Direct determination of carbon and nitrogen contents 573of natural bacterial assemblages in marine environments, Appl. Environ. Microbiol., 64(9), 33525743358, 1998.

575Gattuso, J. P., Frankignoulle, M. and Smith, S. V: Measurement of community metabolism and 576significance in the coral reef $\mathrm{CO} 2$ source-sink debate., Proc. Natl. Acad. Sci. U. S. A., 96(23), 1301757713022, doi:10.1073/pnas.96.23.13017, 1999.

578Giering, S. L. C., Sanders, R., Lampitt, R. S., Anderson, T. R., Tamburini, C., Boutrif, M., Zubkov, M. V, 579Marsay, C. M., Henson, S. a, Saw, K., Cook, K. and Mayor, D. J.: Reconciliation of the carbon budget in 
580the ocean's twilight zone., Nature, 507(7493), 480-483, doi:10.1038/nature13123, 2014.

581Goutx, M., Momzikoff, A., Striby, L., Andersen, V., Marty, J. . and Vescovali, I.: High-frequency fluxes of 582labile compounds in the central Ligurian Sea, northwestern Mediterranean, Deep Sea Res. Part I 5830ceanogr. Res. Pap., 47(3), 533-556, doi:10.1016/S0967-0637(99)00101-6, 2000.

584Goutx, M., Guigue, C. and Striby, L.: Triacylglycerol biodegradation experiment in marine 585environmental conditions: definition of a new lipolysis index, Org. Geochem., 34(10), 1465-1473, 586doi:10.1016/S0146-6380(03)00119-0, 2003.

587Goutx, M., Wakeham, S. G., Lee, C., Duflos, M., Guigue, C., Liu, Z., Moriceau, B., Sempéré, R., Tedetti, 588M. and Xue, J.: Composition and degradation of marine particles with different settling velocities in 589the northwestern Mediterranean Sea, Limnol. Oceanogr., 52(4), 1645-1664, 590doi:10.4319/lo.2007.52.4.1645, 2007.

591Harris, R. P.: Zooplankton grazing on the coccolithophore Emiliania huxleyi and its role in inorganic 592carbon flux, Mar. Biol., 119(3), 431-439, doi:10.1007/BF00347540, 1994.

593Hedges, J. I., Baldock, J. A., Gélinas, Y., Lee, C., Peterson, M. and Wakeham, S. G.: Evidence for non594selective preservation of organic matter in sinking marine particles, Nature, 409(6822), 801-4, 595doi:10.1038/35057247, 2001.

596Henson, S. A., Sanders, R., Madsen, E., Morris, P. J., Le Moigne, F. and Quartly, G. D.: A reduced 597estimate of the strength of the ocean's biological carbon pump, Geophys. Res. Lett., 38(4), 598doi:10.1029/2011GL046735, 2011.

599Holligan, P. M., Fernández, E., Aiken, J., Balch, W. M., Boyd, P., Burkill, P. H., Finch, M., Groom, S. B., 600Malin, G., Muller, K., Purdie, D. A., Robinson, C., Trees, C. C., Turner, S. M. and van der Wal, P.: A 601biogeochemical study of the coccolithophore, Emiliania huxleyi , in the North Atlantic, Global 602Biogeochem. Cycles, 7(4), 879-900, doi:10.1029/93GB01731, 1993.

603Houdan, A., Véron, B., Claquin, P., Lefebvre, S. and Poncet, J.-M.: Cryopreservation of the 604coccolithophore, Emiliania huxleyi (Haptophyta, Prymnesiophyceae), J. Appl. Phycol., 17(5), 413-422, 605doi:10.1007/s10811-005-0065-5, 2005. 
606Iglesias-Rodriguez, M. D., Armstrong, R., Feely, R., Hood, R., Kleypas, J., Milliman, J. D., Sabine, C. and 607Sarmiento, J.: Progress made in study of ocean's calcium carbonate budget, Eos, Trans. Am. Geophys. 608Union, 83(34), 365-375, doi:10.1029/2002EO000267, 2002.

609Ignatiades, L., Gotsis-Skretas, O., Pagou, K. and Krasakopoulou, E.: Diversification of phytoplankton 610community structure and related parameters along a large-scale longitudinal east-west transect of 611the Mediterranean Sea, J. Plankton Res., 31(4), 411-428, doi:10.1093/plankt/fbn124, 2009.

612Ingalls, A. E., Lee, C., Wakeham, S. G. and Hedges, J. I.: The role of biominerals in the sinking flux and 613preservation of amino acids in the Southern Ocean along $170^{\circ} \mathrm{W}$, Deep Sea Res. Part II Top. Stud. 614Oceanogr., 50(3-4), 713-738, doi:10.1016/S0967-0645(02)00592-1, 2003.

615Iversen, M. H. and Ploug, H.: Ballast minerals and the sinking carbon flux in the ocean: carbon-specific 616respiration rates and sinking velocity of marine snow aggregates, Biogeosciences, 7(9), 2613-2624, 617doi:10.5194/bg-7-2613-2010, 2010.

618Jacquet, S. H. M., Dehairs, F., Cardinal, D., Navez, J. and Delille, B.: Barium distribution across the 619Southern Ocean frontal system in the Crozet-Kerguelen Basin, Mar. Chem., 95(3-4), 149-162, 620doi:10.1016/j.marchem.2004.09.002, 2005.

621Jansen, H. and Wolf-Gladrow, D. A.: Carbonate dissolution in copepod guts: A numerical model, Mar. 622Ecol. Prog. Ser., 221, 199-207, doi:10.3354/meps221199, 2001.

623de Jesus Mendes, P. a. and Thomsen, L.: Effects of Ocean Acidification on the Ballast of Surface 624Aggregates Sinking through the Twilight Zone, PLoS One, 7(12), e50865, 625doi:10.1371/journal.pone.0050865, 2012.

626de Jesus Mendes, P. A., Thomsen, L., Holscher, B., de Stigter, H. C. and Gust, G.: Pressure effects on 627the biological degradation of organo-mineral aggregates in submarine canyons, Mar. Geol., 246(2-4), 628165-175, doi:10.1016/j.margeo.2007.05.012, 2007.

629Karner, M. and Fuhrman, J. A.: Determination of Active Marine Bacterioplankton: a Comparison of 630Universal 16S rRNA Probes, Autoradiography, and Nucleoid Staining, Appl. Environ. Microbiol., 63(4), 6311208-13, 1997. 
632Keller, M. D., Selvin, R. C., Claus, W. and Guillard, R. R. L.: Media for the culture of oceanic 633ultraphytoplankton, J. Phycol., 23(4), 633-638, doi:10.1111/j.1529-8817.1987.tb04217.x, 2007.

634Klaas, C. and Archer, D. E.: Association of sinking organic matter with various types of mineral ballast 635in the deep sea: Implications for the rain ratio, Global Biogeochem. Cycles, 16(4), 63-1-63-14, 636doi:10.1029/2001GB001765, 2002.

637Knappertsbusch, M.: Geographic-Distribution of Living and Holocene Coccolithophores in the 638Mediterranean-Sea, Mar. Micropaleontol., 21(1-3), 219-247, 1993.

639Kogure, K. and Koike, I.: Particle counter determination of bacterial biomass in seawater, Appl. 640Environ. Microbiol., 53(2), 274-277, 1987.

641Kwon, E. Y., Primeau, F. and Sarmiento, J. L.: The impact of remineralization depth on the air-sea 642carbon balance, Nat. Geosci., 2(9), 630-635, doi:10.1038/ngeo612, 2009.

643De La Rocha, C. L. and Passow, U.: Factors influencing the sinking of POC and the efficiency of the 644biological carbon pump, Deep Sea Res. Part II Top. Stud. Oceanogr., 54(5-7), 639-658, 645doi:10.1016/j.dsr2.2007.01.004, 2007.

646Manz, W., Amann, R., Ludwig, W., Wagner, M. and Schleifer, K.-H.: Phylogenetic Oligodeoxynucleotide 647Probes for the Major Subclasses of Proteobacteria: Problems and Solutions, Syst. Appl. Microbiol., 64815(4), 593-600, doi:10.1016/S0723-2020(11)80121-9, 1992.

649Manz, W., Amann, R., Ludwig, W., Vancanneyt, M. and Schleifer, K. H.: Application of a suite of $16 \mathrm{~S}$ 650rRNA-specific oligonucleotide probes designed to investigate bacteria of the phylum cytophaga651flavobacter-bacteroides in the natural environment, Microbiology, 142(5), 1097-1106, 652doi:10.1099/13500872-142-5-1097, 1996.

653Milliman, J. D., Troy, P. J., Balch, W. M., Adams, A. K., Li, Y. H. and Mackenzie, F. T.: Biologically 654mediated dissolution of calcium carbonate above the chemical lysocline?, Deep. Res. Part I Oceanogr. 655Res. Pap., 46(10), 1653-1669, doi:10.1016/S0967-0637(99)00034-5, 1999.

656Moeseneder, M. M., Winter, C. and Herndl, G. J.: Horizontal and vertical complexity of attached and 657free-living bacteria of the eastern Mediterranean Sea, determined by $16 \mathrm{~S}$ rDNA and $16 \mathrm{~S}$ rRNA 
658fingerprints, Limnol. Oceanogr., 46(1), 95-107, doi:10.4319/lo.2001.46.1.0095, 2001.

659Le Moigne, F. A. C., Gallinari, M., Laurenceau, E. and De La Rocha, C. L.: Enhanced rates of particulate 660organic matter remineralization by microzooplankton are diminished by added ballast minerals, 661Biogeosciences, 10(9), 5755-5765, doi:10.5194/bg-10-5755-2013, 2013.

662Nanninga, H. and Tyrrell, T.: Importance of light for the formation of algal blooms by Emiliania huxleyi, 663Mar. Ecol. Prog. Ser., 136, 195-203, doi:10.3354/meps136195, 1996.

664Panagiotopoulos, C., Sempéré, R., Obernosterer, I., Striby, L., Goutx, M., Van Wambeke, F., Gautier, S. 665and Lafont, R.: Bacterial degradation of large particles in the southern Indian Ocean using in vitro 666incubation experiments, Org. Geochem., 33(8), 985-1000, doi:10.1016/S0146-6380(02)00057-8, 6672002.

668Passow, U.: Switching perspectives: Do mineral fluxes determine particulate organic carbon fluxes or 669vice versa?, Geochemistry, Geophys. Geosystems, 5(4), doi:10.1029/2003GC000670, 2004.

670Passow, U. and De La Rocha, C. L.: Accumulation of mineral ballast on organic aggregates, Global 671Biogeochem. Cycles, 20(1), doi:10.1029/2005GB002579, 2006.

672Ploug, H. and Bergkvist, J.: Oxygen diffusion limitation and ammonium production within sinking 673diatom aggregates under hypoxic and anoxic conditions, Mar. Chem., 176, 142-149,

674doi:10.1016/j.marchem.2015.08.012, 2015.

675Ploug, $\mathrm{H}$. and Grossart, $\mathrm{H} .:$ Bacterial production and respiration in suspended aggregates - a matter of 676the incubation method, Aquat. Microb. Ecol., 20(1), 21-29, doi:10.3354/ame020021, 1999.

677Ploug, H., Iversen, M. H. and Fischer, G.: Ballast, sinking velocity, and apparent diffusivity within 678marine snow and zooplankton fecal pellets: Implications for substrate turnover by attached bacteria, 679Limnol. Oceanogr., 53(5), 1878-1886, doi:10.4319/lo.2008.53.5.1878, 2008.

680Porter, K. G. and Feig, Y. S.: The use of DAPI for identifying and counting aquatic microflora, Limnol. 6810ceanogr., 25, 943-948, doi:10.4319/lo.1980.25.5.0943, 1980.

682Poulton, A. J., Adey, T. R., Balch, W. M. and Holligan, P. M.: Relating coccolithophore calcification rates 683to phytoplankton community dynamics: Regional differences and implications for carbon export, 
684Deep Sea Res. Part II Top. Stud. Oceanogr., 54(5-7), 538-557, doi:10.1016/j.dsr2.2006.12.003, 2007. 685Le Quéré, C., Takahashi, T., Buitenhuis, E. T., Rödenbeck, C. and Sutherland, S. C.: Impact of climate 686change and variability on the global oceanic sink of CO 2, Global Biogeochem. Cycles, 24(4), GB4007, 687doi:10.1029/2009GB003599, 2010.

688Sawada, K. and Shiraiwa, Y.: Alkenone and alkenoic acid compositions of the membrane fractions of 689Emiliania huxleyi, Phytochemistry, 65(9), 1299-1307, doi:10.1016/j.phytochem.2004.03.015, 2004. 690Sekar, R., Pernthaler, A., Pernthaler, J., Warnecke, F., Posch, T. and Amann, R.: An Improved Protocol 691for Quantification of Freshwater Actinobacteria by Fluorescence In Situ Hybridization, Appl. Environ. 692Microbiol., 69(5), 2928-2935, doi:10.1128/AEM.69.5.2928, 2003.

693Sempéré, R., Yoro, S. O., Van Wambeke, F. and Charrière, B.: Microbial decomposition of large organic 694particles in the northwestern Mediterranean Sea: an experimental approach, Mar. Ecol. Prog. Ser., 695198, 61-72, 2000.

696Siegel, D. A., Buesseler, K. O., Doney, S. C., Sailley, S. F., Behrenfeld, M. J. and Boyd, P. W.: Global 697assessment of ocean carbon export by combining satellite observations and food-web models, Global 698Biogeochem. Cycles, 28(3), 181-196, doi:10.1002/2013GB004743, 2014.

699Simon, M., Grossart, H., Schweitzer, B. and Ploug, H.: Microbial ecology of organic aggregates in 700aquatic ecosystems, Aquat. Microb. Ecol., 28, 175-211, doi:10.3354/ame028175, 2002.

701Tamburini, C., Garcin, J., Grégori, G., Leblanc, K., Rimmelin, P. and Kirchman, D.: Pressure effects on 702surface Mediterranean prokaryotes and biogenic silica dissolution during a diatom sinking 703experiment, Aquat. Microb. Ecol., 43(3), 267-276, doi:10.3354/ame043267, 2006.

704Tamburini, C., Goutx, M., Guigue, C., Garel, M., Lefèvre, D., Charrière, B., Sempéré, R., Pepa, S., 705Peterson, M. L., Wakeham, S. and Lee, C.: Effects of hydrostatic pressure on microbial alteration of 706sinking fecal pellets, Deep Sea Res. Part II Top. Stud. Oceanogr., 56(18), 1533-1546, 707doi:10.1016/j.dsr2.2008.12.035, 2009.

708Teira, E., Reinthaler, T., Pernthaler, A., Pernthaler, J. and Herndl, G. J.: Combining Catalyzed Reporter 709Deposition-Fluorescence In Situ Hybridization and Microautoradiography To Detect Substrate 
710Utilization by Bacteria and Archaea in the Deep Ocean, Society, 70(7), 4411-4414,

711doi:10.1128/AEM.70.7.4411, 2004.

712Thiele, S., Fuchs, B. M., Amann, R. and Iversen, M. H.: Colonization in the Photic Zone and Subsequent 713Changes during Sinking Determine Bacterial Community Composition in Marine Snow, Appl. Environ. 714Microbiol., 81(4), 1463-1471, doi:10.1128/AEM.02570-14, 2015.

715Treguer, P. and Pondaven, P.: Global change. Silica control of carbon dioxide, Nature, 406(6794), 3587169, doi:10.1038/35019236, 2000.

717Turley, C. M.: Formation, vertical flux and remineralisation of aggregates in the ocean: a short review, 718Arch. fur Hydrobiol. Beih. Ergebnisse der Limnol., 1992.

719Turley, C. M.: The effect of pressure on leucine and thymidine incorporation by free-living bacteria 720and by bacteria attached to sinking oceanic particles, Deep Sea Res. Part I Oceanogr. Res. Pap., 40(1172112), 2193-2206, doi:10.1016/0967-0637(93)90098-N, 1993.

722Turley, C. M. and Mackie, P. J.: Biogeochemical significance of attached and free-living bacteria and 723the flux of particles in the NE Atlantic Ocean, Mar. Ecol. Prog. Ser., 115(1-2), 191-204, 724doi:10.3354/meps115191, 1994.

725Turley, C. M. and Mackie, P. J.: Bacterial and cyanobacterial flux to the deep NE atlantic on 726sedimenting particles, Deep. Res. Part I, 42(8), 1453-1474, doi:10.1016/0967-0637(95)00056-C, 1995. 727Wannicke, N., Frindte, K., Gust, G., Liskow, I., Wacker, A. 769, Meyer, A. and Grossart, H.-P.: Measuring 728bacterial activity and community composition at high hydrostatic pressure using a novel experimental 729approach: A pilot study, FEMS Microbiol. Ecol., 91(5), 1-37, 2015.

730Wollast, R. and Chou, L.: Distribution and fluxes of calcium carbonate along the continental margin in 731the Gulf of Biscay, Aquat. Geochemistry, 4(3-4), 369-393, 1998.

732Wollast, R. and Chou, L.: The carbon cycle at the ocean margin in the northern Gulf of Biscay, Deep. 733Res. Part II Top. Stud. Oceanogr., 48(14-15), 3265-3293, doi:10.1016/S0967-0645(01)00040-6, 2001. 734 


\section{Supplementary data}

736Supplementary Table 1: Lipid proportions (\% Total Particulate Lipids) in the E. huxleyi culture at day 4 737(Bell and Pond, 1996) and during Exp B. Numbers 1, 2 and 3 stand for replicate incubations. 738Chloroplastic: pigments + monogalactosyldiacylglycerol, Phospholipids: diphosphatidylglycerides + 739phosphatidylglycerides + phosphatidylethanolamine + phosphoinositol + phosphatidylcholine, ST: 740sterols, Neutral: wax esters + methyl esters + ketones + triglycerides + Free Fatty Acids + fatty 741alcohols, Metab: Monoglycerides + DiGlycerides, HC: Hydrocarbons.

$\begin{array}{ccccccc}\text { E. huxleyi 4 days } & \text { Chloroplastic } & \text { Phospholipids } & \text { Sterols } & \text { Neutral } & \text { Metab } & \text { HC } \\ \begin{array}{c}\text { (Bell and Pond, 1996) } \\ \text { t0-1 }\end{array} & 41.3 \pm 0.8 & 21.5 \pm 0.4 & 3.6 \pm 0.4 & 23.3 \pm 1.3 & \text { ND } & 9.4 \pm 0.3 \\ \text { t0-2 } & 39.3 & 22.5 & 2.4 & 23.2 & 4.0 & 7.6 \\ \text { t0-3 } & 44.8 & 18.2 & 3.3 & 17.9 & 5.5 & 8.4 \\ \text { ATMt10-1 } & 46.5 & 16.6 & 3.8 & 19.2 & 4.4 & 8.1 \\ \text { ATMt10-2 } & 10.8 & 5.0 & 0.0 & 50.3 & 0.0 & 31.2 \\ \text { ATMt10-3 } & 32.5 & 3.4 & 3.1 & 13.6 & 0.0 & 43.6 \\ \text { HPt10-1 } & 20.7 & 5.8 & 2.5 & 37.7 & 0.0 & 20.6 \\ \text { HPt10-2 } & 22.5 & 3.6 & 1.9 & 37.2 & 5.2 & 25.6 \\ \text { HPt10-3 } & 19.8 & 6.8 & 0.0 & 43.1 & 0.0 & 21.0 \\ & 23.0 & 4.6 & 0.0 & 35.3 & 0.0 & 25.3\end{array}$

742Supplementary Figure 1: Photographs of the GF/F filters from Exp B at ATMt10 (A, B, C) and HPt10 (D, $743 \mathrm{E}, \mathrm{F}) . \mathrm{A}-\mathrm{C}$, and $\mathrm{B}-\mathrm{F}$ are the replicate incubations. Arrows point at some of the large visible aggregates 744in HPt10 incubations.
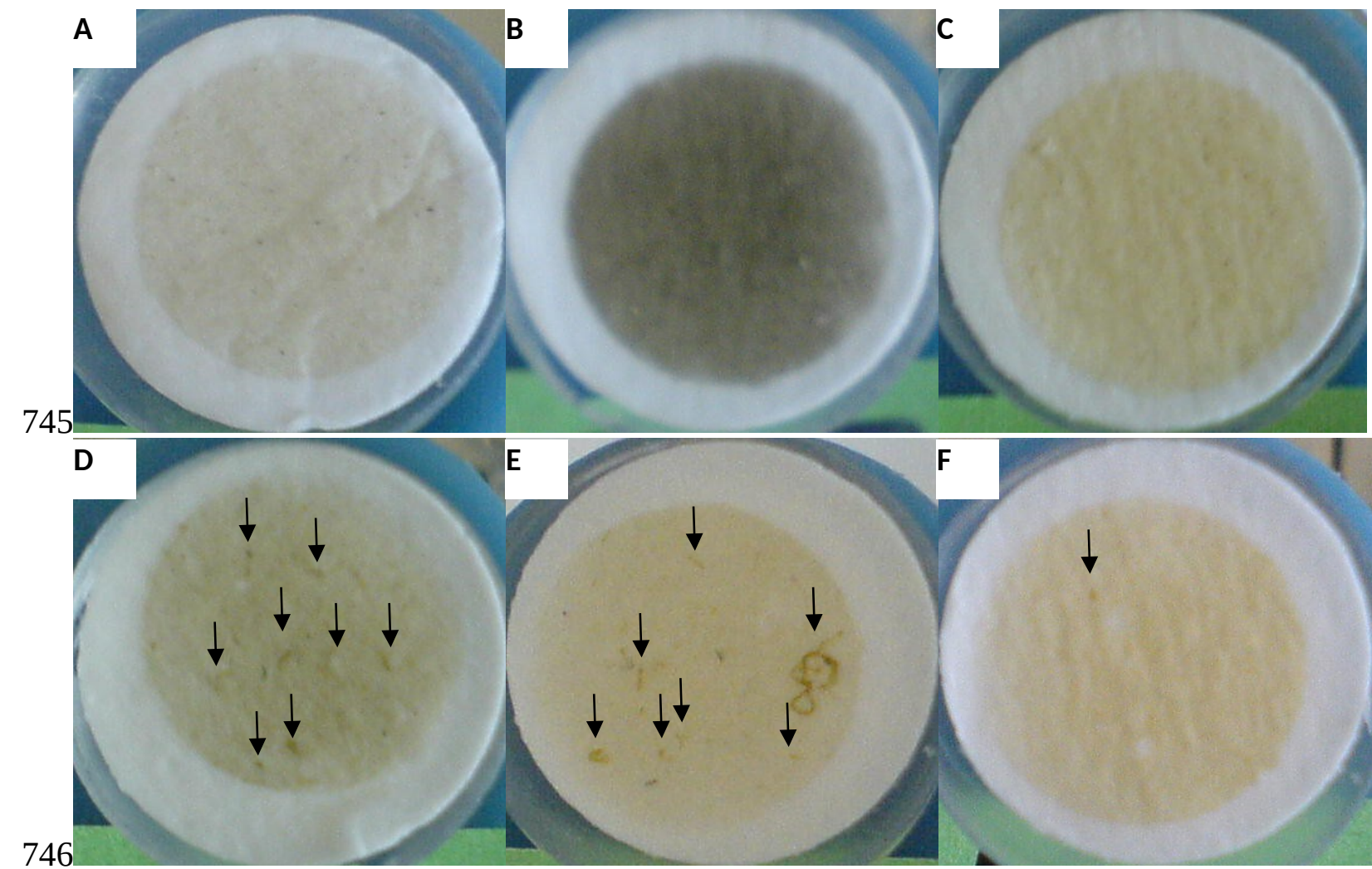


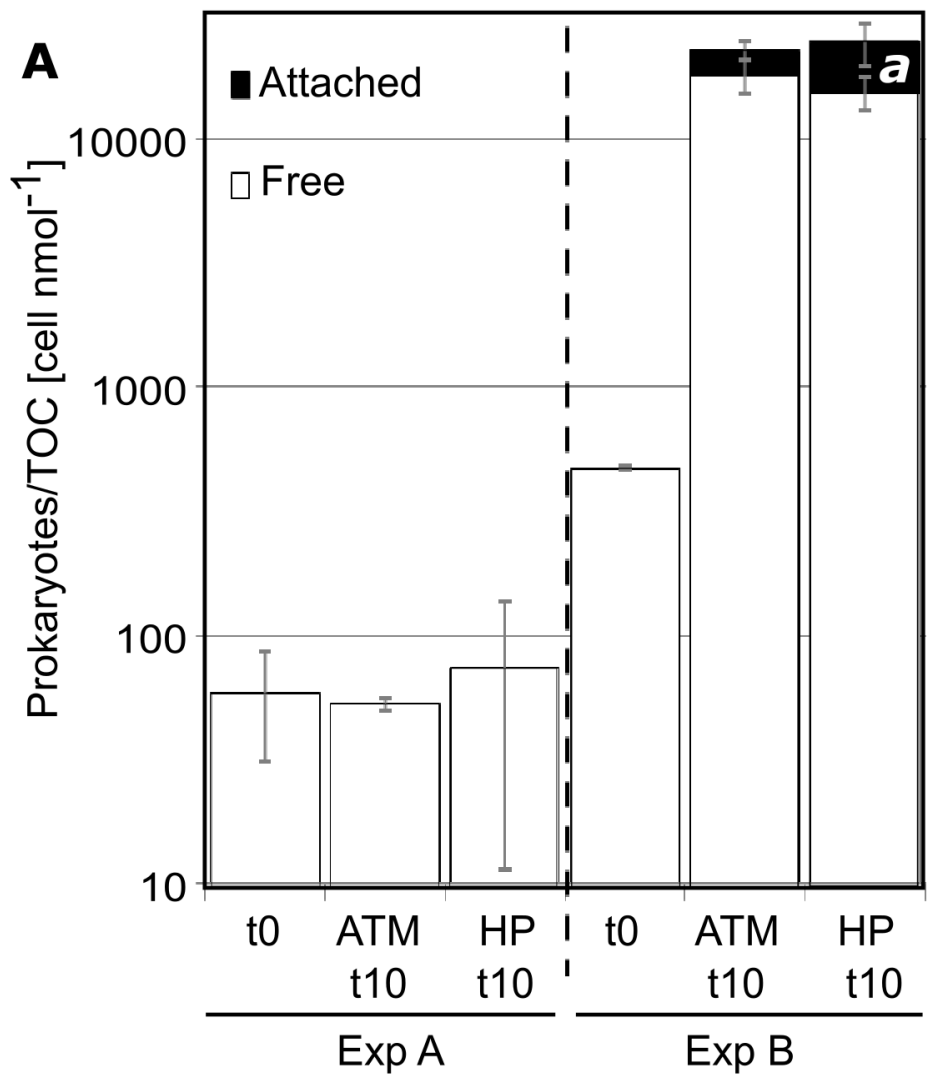




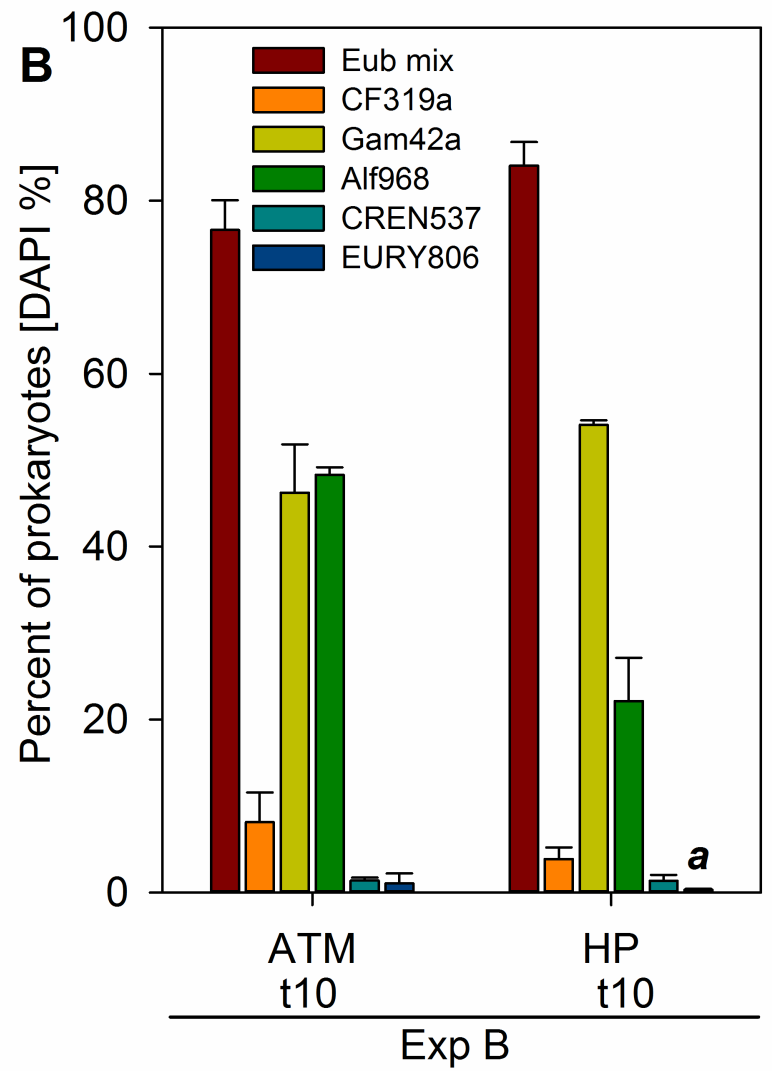


